UNITED STATES

DEPARTMENT OF THE INTERIOR

GEOLOGICAL SURVEY

SUMMARY OF REFERENCES TO MINERAL OCCURRENCES

(OTHER THAN MINERAL FUELS AND CONSTRUCTION MATERIALS)

IN THE CORDOVA QUADRANGLE, ALASKA

\author{
By \\ Edward H. Cobb
}

\author{
Open-Eile Report 79-973 \\ 1979
}

\begin{abstract}
This report is preliminary and has not been edited or reviewed Eor conformity with Geologlcal Survey standards and nomenc lacure.
\end{abstract}




\section{Inc roduction}

Thls sumary of references is designed to aid in 1 ibrary research on metallic and nonmetallic (other than mineral fuels and constructian materials) mineral occurrences in the Cordova quadrangle, Alaska. References co most reports of the Ceological Survey, U. S. Bureau of Mines, and Scate of Alaska Division of Ceological and Geophysical Surveys and its predecessor agencies released before January 1, 1979, are included. Certain, mainly statistical, reports such as the annual Minerals Yearbook of the U.S. Bureau of Mines and the biennial and annual reporcs of the Alaska Division of Geological and Ceophysical Surveys and its predecessor agencies are not included. Also not included are data on many prospecrs and claims about which lictle more than their locations is known (Eor example, many of chose in Condon, 1965 (I-453) and some in Mackevere and Holloway, 1977 (OF-77-169A), p. 15). These omissions should noc be interpreted as a Judgement on my part that the prospects and claims are not valid mineral occurrences, but only that chere are insufficienc data to describe any mineral deposits that might be present.

This report is divided inco three parts: a section made up of summaries of references arranged alphabetically by occurrence name; a section that lists syronyms for names in the first section, claim nares, and the names of operators and owners of mines and prospects; and a section chat Lists, by auchor, all references in the first section and in these introduccory paragraphs. 


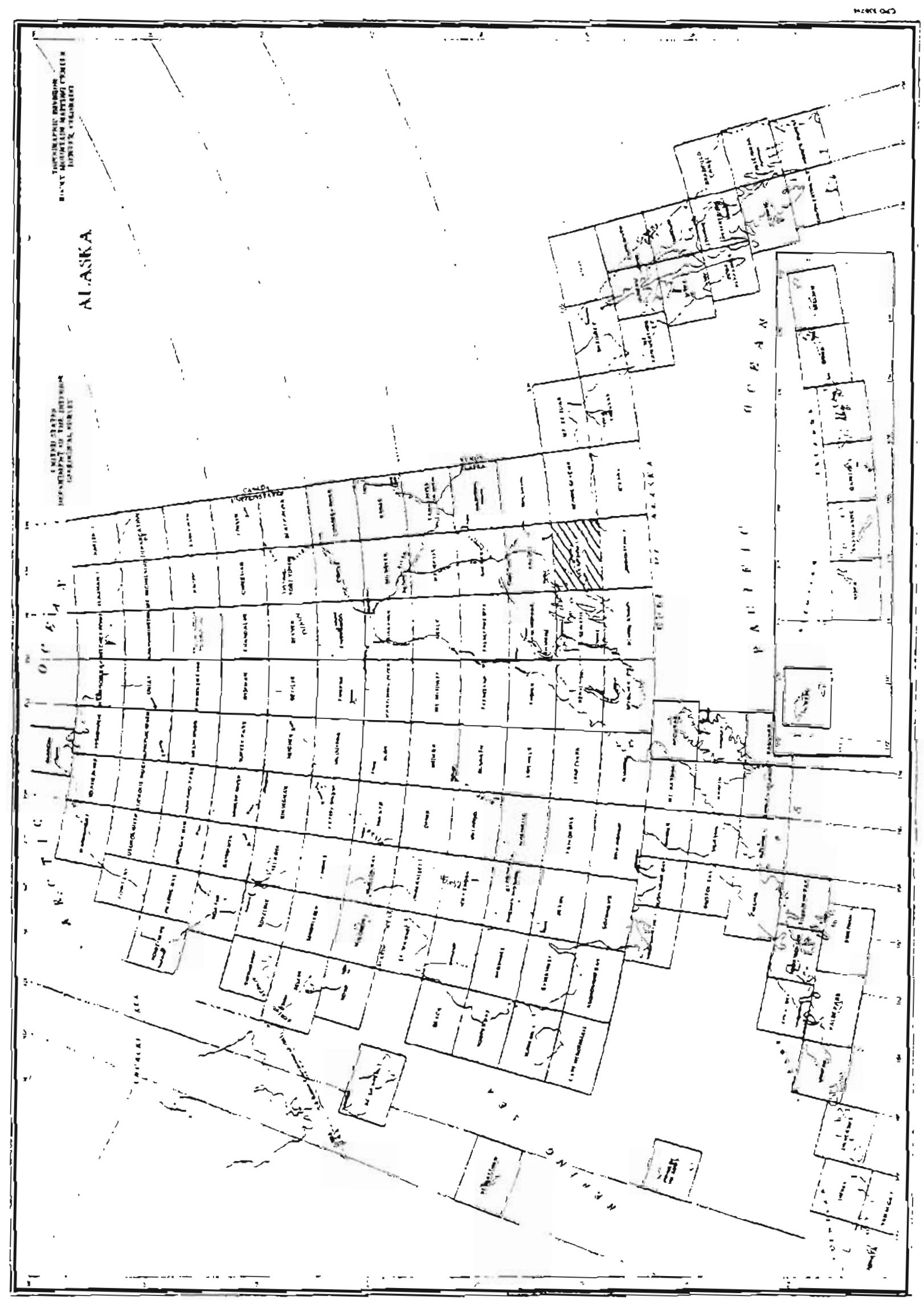


Summaries of References

For each mineral occurrence there is a page that gives the name of the occurrence; the mineral commoditles present ( 1 isted alphabetcally), the mining discrict (Ransome and Kerns, 1954 (IC 7679)) in which che occurrence is located; the name of the 1:250,000-scale topographic quadrangle (Cordova); coordinates (as described by Cobb and KAchadoorlan, 196L (B 1139), p. 3-4); the mecallic mineral resources map number (MF-392) and the occurrence number on the map if the occurrence is shown; and the laticude and longitude of the occurrence. These daca, presenced at the top of the page, are followed by a short, general summary of the published information on the occurrence. This is followed (concinued on addictonal pages iE necessary) by more detailed summaries, arranged chronologically, of ald references to the occurrences. In a few instances dara from the field notes of geologists are also included, but I made no artempe to study all of the possibly applicable nocebooks. Macerial in brackecs is interpretive or explanatory and is not in the summarized reference.

Proper names of mines, prospects, and other mineral occurcences are given if such names appeat in the reports summarized. If a part of a proper name is not always used in a reference, that part of the name is shown in parentheses. If a deposic does not have a proper name, but is near a named geographic feature, the name of that feature is shown in parentheses in lieu of a proper name.

Citations are given in standard blbliographic fomat with che excepcion that references to reporcs and maps in numbered publicacion series also show, in parentheses, an abbreviation Eor the report of map series and the report or map number. Abbreviation used are:

$\begin{array}{ll}\text { AOF } & \text { Alaska Division of Geological and Geolphysical Surveys } \\ \text { Open-Eile Report } \\ \text { g } & \text { U.S. Geological Survey Bulletin } \\ \text { BMB } & \text { U.S. Bureau of Mines Bullecin } \\ \text { C } & \text { U.S. Geological Survey Circular } \\ \text { I } & \text { U.S. Geological Survey Miscelianeous Geologic Investi- } \\ & \text { gation bap } \\ \text { IC } & \text { U.S. Bureau of Mines Informarion Circular } \\ \text { OF } & \text { U.S. Geological Survey Open-file Report } \\ \text { MF } & \text { U.S. Geological Survey Miscellaneous Field Studies Map } \\ \text { P } & \text { U.S. Geological Survey Professional Paper } \\ \text { RI } & \text { U.S. Bureau of Mines Report of Investigations }\end{array}$


Sumaries are as I made tham while reading the cited reports. I made no attempt to use complete sentences and did not edit for grammatical consistency, alchough I cried to edit out ambiguities. 
Alaska Commercial Co.

Prince William Sound district

$M R-392,10 C \cdot 14$
Copper, Gold, Lead, Silver, Zinc.

Cordova $(3.9,15.0)$

6005 !'N, 146032 '

Sumary: Sice of original copper discovery in area, 1897 . Over $500 \mathrm{ft}$. of workings, malnly driven before 1905, when about 70 cons of ore was shipped. Most recent activity reported was in 1915. Ore in 2 sulfide lenses in shear zone in greenstone (with some incerbedded graywacke and slate) of orca Gp. Sulfides include chalcoyrice, pyrthocite, sphalerice, galena, arsenopyrite, and cubanice(?); as much as $0.18 \mathrm{oz}$. gold and $0.26 \mathrm{oz}$. silver a con in assays. Propercy eventually owned by Threeman Mining Co. Includes references to: A.C. (Co.), Copper Mountain, Jacobson. See also (Bligh I.).

Schrader, 1900, 9. 4l7m4l8 - Copper ore in talus led to discovery of vein in 1897; in shear zone in greenstone or amphibolite schisc. Ore consists of chalcopyrite, boxnite, marcasite, pyrite, and some quartz and speculartice. Samples contalned $11.4 \%$ and $12.5 \%$ copper.

Granc, 1906 (B 284), p. 83-84 -- Shear zone in greenstone is about $4 \mathrm{ft}$. thick, strikes $\mathrm{N} 68^{\circ} \mathrm{E}$, and dips $75^{\circ}-80^{\circ} \mathrm{N}$. Concains layer pyrrhotice and chalcopyrice 2-8 in. thick. About 70 tons of ore was shipped in 1905. Tunnel run $412 \mathrm{ft}$. to undercut ore boby; did not reach it unless a barren, narrow shear zone represents the vein.

Capps and Johnson, 1913 (B 542), p. 119-121 - Preliminary to Capps and Johnson, 1915 (B 605).

Johnson, 1914 (B 592), p. 241 - Underground development, 1913.

Capps and Johnson, 1915 (B 605), p. 13 -- Firsc claim scaked, 1897.

p. 52-54, 56 - Data from older reports. Part of a quotacion from Emerson, B. K., 1904 in Harriman Alaska Expedition, General Geology, Alaska, v. 4, p. $24-25$, Eollows: "The deposit of copper ore is a mass of quartz, with chalcopyrite, pyrrhotite, and small amounts of galena and sphalerite, occupying a shear zone in a rock of serpencinous character."

p. 70-7l - Arsenopyrite appears to bave been the first sulfide to form.

p. 107-108 -- Located in 1897; more than $500 \mathrm{ft}$. of underground workings in 1898-99 and some high-grade ore shipped. More development, 1912-13. Councry rock mainly greenstone; some interbedded slate and graywacke. Ore in shear zone abour $30 \mathrm{ft}$. wide that includes large lenses of unsheared greenstone. Sulfides in most highly sheared material and in joints in unsheared rock. Highly mineralized zone is 2-10 (average 4) ft. wide; strikes $N 850 \mathrm{~W}$, dips $600 \mathrm{~N}$, and is traceable along strike for about $250 \mathrm{fr}$. Ore probably formed by replacement of greenstone with some cementacion of small fractures. Sulfides are chalcopyrlee, pyrrhotite, sphalexice, galena, arsenopyrice, and an undecermined sulfide [cubanice?]; gold and silver reported in assays. 
Alaska Commercial Co. -- cont.

Johnson, 1915 (B 622), p. 133 - Ore reported to have been found, 1914. Johnson, 1916 (B 642), p. 140 -- Crosscut(s) driven by Threeman Mining Co., 1915.

Smich, 1917 (BMB 142), p. 43 -- Owned by Three Man Mining Co.

Smich, 1917 (BMB 153), p. 50 - Same as above.

Moffit and Fellows, 1950 (B 963-B), p. 48 -- First copper discovery in Prince William Sound, 1897.

p. 59 -- In 1915 included 3 cunnels with a tocal length of more than $532 \mathrm{ft}$. Several tons of high-grade material reporced to have been shipped.

Mihelich and Wells, 1957 (RI 5320), p. 3 -- Claim data.

p. 6 - Were no ore shipments [does not agree with data in some of older reports].

p. 14 - Mine map. Samples assayed contained as souch as $6.0 \%$ $\mathrm{Cu}, 1.4 \% 2 \mathrm{n}, 0.26 \mathrm{oz}$. a con $\mathrm{Ag}$, and $0.18 \mathrm{oz}$. a ton $\mathrm{Au}$.

P. 18-19 -- Prospect located in 1897. Drift driven 200 ft. from cunnel; along shear zone; exposed 2 lenses of chalcopyrite, pyrrhotice, and pyrtie with total length of over $100 \mathrm{ft}$. and $1.5-3.2 \mathrm{ft}$. thick. Ocher exploratory openings and crenches not visible when visited by USBM, 1955.

Mackevet and Holloway, 1977 (OF 77-169A), p. 14, loc. 10 - References to Capps and Johnson, 1915 (B 605), and Mihelich and Wells, 2957 (RI 5320). Country rock mainly greenstone of Orca Gp. 
Banzer

Prince William Sound district $M F-392$, loc. 17
Copper, Gold, Lead, Zinc

Cordova $(3.9,14.3)$

$60049^{\prime} \mathrm{N}, 146033^{\prime} \mathrm{W}$

Sumary: Quartz scringers and bunches in slate of Orca Gp. contain chalcopyrite, pyrrhotite, pyrite, sphalerite, galena, and gold; assays as high as abour 2.42 oz. gold a ton reported. A lictle work done in early 1900's, but no recorded production. Banzer also is reported to have done some work in 1917 on a copper prospect somewhere near che head of Port Fidalgo (Johnson, 1919 (B 692), p. 149).

Capps and Johnson, 1913 (B 542), p. 123-124 -- Preliminary to Capps and Johnson, 1915 (B 605).

Capps and Johnson, 1915 (B 605), p. 112 -- 2 shafts and several hundred feet of stripping before 1912. Country rock concorted slate and greenstone; many stringers and bunches of quartz in slate. Quartz on dump contains chalcopyrite, pyrrhotice, sphalerite, and galena; a lictle calcice gangue. Assays as high as $\$ 50$ [about $2.42 \mathrm{oz}$. a ton in gold reported; may not have been an average sample. Mackevere and Holloway, 1977 (OF 77-169A), p. 14, Loc. 12 -- Reference ro Capps and Johnson, 1915 (B 605). Bedrock is Orca Gp. 
Bayview

Prince Whlliam Sound district
Copper(")

Cordova :6.25, 17.45) approx. $61^{\circ} 00^{\prime} \mathrm{N}, 146^{\circ} 16^{\prime} \mathrm{W}$ approx.

Sumary: Copper prospecr; claim locared on a minerallzed rone in greenscone at head of Solomon Gulch. No data on deposit other than approximate location.

Johnson, 1919 (B 692), p. 165 -- Copper prospe:c nearly 2,500 Et. above sea level on Solomon Gulch. [Other Solonon Gulch prospects and mine are in Valdez quad.]

p. 171 - Claim staked on a minerali sed zone in large greenscone area that crosses head of solomon iulch at elevacion of about 2,500 ft.; $1 \frac{1}{2}$ mi. south of Midas mine.

Mulligan, 1974 (IC 8626), p. 22 -D Data from Jishnson, 1919 (B 692), p. 171 [not clted]. [Incorrectly located In valdez quad.] 
Bear Creek Mining Co.

Prince William Sound district

MF $-392,10 \mathrm{C}, 27$
Cold

Cordova $(15.6,8.75)$

$60^{\circ} 29^{\prime} \mathrm{N}, 145^{\circ} 12^{\prime} \mathrm{w}$

Summary: Has been development work on several clalms. Geology similar to chat at Mckinley Lake. See also Lucky Strike Mining. Co.

Chapin, 1913 (B 542), p. 79-80 -- Several claims on which development work has been done. Geology similar to that at Mckinley Lake. [See Lucky Strike Mining Co. Lor description.]

Mackevect and Holloway, 1977 (OF 77-169A), p. 15, loc. 21 -- Reference to above. In slate and graywacke of Orca Gp. 
(BIIgh I.)

Prince William Sound district

$\mathrm{MF}-392,10 \mathrm{C} \cdot 2$
Gold

Cordova $(2.25,15.3)$ approx. $60053^{\prime} \mathrm{N}, 146045^{\prime} \mathrm{W}$ approx.

Summary: Quartz pod in rocks of Orca $G p$. (Paleocene) contained much gold (assay as high as about $121 \mathrm{oz}$. a con reported) was mined out in early 1900's.

Capps and Johnson, 1913 (B 542), p. 123 -- tereliminary to Capps and Johnson, 1915 (B 605).

Capps and Johnson, 1915 (B 605), p. 112 - Old prospect of Alaska Commercial Co. at $\mathrm{NE}$ corner of island on a mass of quartz sald to have assayed as high as $\$ 2,500$ [about 121 az.] a con in gold. Reported to have been worked out. Shaft caved and nothing Mackevertiole holtoway, 1977 (OF 77-169A), p. 14, loc. 2 -- Reference
to Capps and Johnson, 1915 (B 615). Gold-bearing quartz pod in Orca Gp. (Paleocene). 
Nizina discrict

Cordova $(24.3,18.0)$

$M F-392,10 c .31$

$60^{\circ} 00^{\prime} \mathrm{N}, 144^{\circ} 08^{\prime} \mathrm{W}$

Summary: In early 1900's there were attempts to mine fine gold from glactofluvial sand and gravel terrace on glaciaced bedrock of Valdez Gp. Total production prabably no more than a few cens of ounces of gold. Includes references to (Threemile Canyon).

Moffit, 1912 (B 520), p. 99-100 - Preliminary co Moffic, 1914 (B 576). Moffit, 1913 (B 576), p. 44 - Yield of placer gold worth no more than a few hundred dollars.

p. 47-48 -- Bench on north side of river about mi. above Threemlle Canyon was belng mined in 1911. Sand and fine gravel containing fine gold rests on glaciated surface of slate or graywacke bedrock. Sluiced with water from a small stream that went dry in the middle of the summer. Fine gold also on river bars. In 1911 one man was working on a small tributary that flows into river in Threemile Canyon; had been more interest in 1907, but returns were dlsappointing.

Cobb, 1973 (8 1374), p. 32 -. In early 1900's were arcempes to mine glaclofluvial deposits.

Henning and Dobey, 1973 (AOF 25), p. 12-13 -- Reference to Moffit, 1914 (日 576).

Mackevect and Holloway, 1977 (OF 77-169A), p. 15, Loc. 24 -- Reference to Moffit, 1914 (B 576). In Valdez Gp. terrane. 
Chisna Consolidated Mining Co. Copper, Gold, Silver

Prince Wllliam Sound district Cordova $(4.0,14.8)$

$\mathrm{MF}-392$, loc. 16

Summary: Chalcopyrite and pyrite in shear zones in greenstone. Best copper assay reported $150.64 \%$; traces of gold and silver. A Little exploration in about 1909.

Capps and Johnson, 1915 (B 605), p. 111-112 -- Company sald to have been promoted in 1909. 40-ft. inclined shaft and a few open curs; only assessment work in recent years [as of 1912 ]. Slightly mineralized schistose greenstone on trace of Landlock thrust.

Mihelich and Wells, 1957 (RI 5320), p. 6 -- In early 1900's was active prospecting, but no production.

p. IS - Map of prospect. Assays of samples showed as much as $0.64 \% \mathrm{Cu}, 0.04 \mathrm{oz}$. a ton silver, and traces of gold.

p. 19 - In upper plate of Landlock thrusc faulc. Explored by 40-ft. inclined shaft sunk in a shear zone about $40 \mathrm{Et}$. wide that scrikes $\mathrm{N} 30^{\circ} \mathrm{W}$ and dips $35^{\circ} \mathrm{NE}$; thin films of chalcopyrite and of pyrice and gouge in fraccures in greenstone. 20-ft. cunnel driven to crosscue a fracture zone $S \mathrm{ft}$. thick that strikes $\mathrm{N} 300 \mathrm{E}$ and dips $35^{\circ} \mathrm{SE}$.

Mackevet and Holloway, 1977 (OF 77-169A), p. 14, loc. IL - References to above. Country rock Orca Go.; mainly greenstone. 
(Cloudman Bay)

Prince William Sound district MF-392, Loc. 3
Copper, Gold, Zlnc

Cordova (2.3, 14.65) approx. $60^{\circ} 50^{\prime} \mathrm{N}, 146^{\circ} 44^{\prime} \mathrm{W}$ approx.

Summary: Stockwork of drusy quarcz veins in slate of Orca Gp. contains chalcopyrice, pyrice, sphalerite and as much as $\$ 4.80$ (about $0.23 \mathrm{oz}$. ) a ton in gold. Some surface scripping before 1912 .

Capps and Johnson, 1913 (B 542), p. 123 -- Preliminary to Capps and Johnson, 1915 (B 605).

Capps and Johnson, 1925 (B 605), p. 112 -- Stockwork of about equal parts slate and drusy quartz is $20-30 \mathrm{ft}$. wide; gouge seam 4 in. wide along one wall and 2 small faults with gouge along the other. Crops out below high tide; stripped back $40 \mathrm{ft}$. from beach. Quartz contains sulfides, including chalcopyrite, pyrite, and sphalerite. Samples across 30-ft. width of stockwork $\operatorname{ran} \$ 2$ to $\$ 4.80$ [a ton, presurnably in gold at $\$ 20.67$ ].

Mackevett and Holloway, 1977 (OF 77-169A), p. 14, 10c. 3 -- Reference to Capps and Johnson, 1915 (B 605). Stockwork in slates of orca Gp. [Shows sb (stibnite) in descripcion; lapsus for $\mathrm{Sl}$ (sphalerite).] 
(Copper Men.)

Prince William Sound discrict
Copper

Cordova $(3.7-3.9,15.0-15.2)$

$60^{\circ} 51^{\prime}-60^{\circ} 52^{\prime} \mathrm{N}, \quad 146032^{\prime}-146035^{\prime} \mathrm{W}$

Summary: Copper deposits in fissure velns in greenstone with small amounts of slate, graywacke, and quartzite. See also: Alagka Commercial Co., Hemple Copper Co., Montezuma, Reynolds-Alaska Development Co. (Landlocked Bay), Standard Copper Mines Co.

Schrader and Spencer, $1901, p .88$-- Fissure-vein copper deposits. Grane, 1906 (B 284), p. 82 -- Country rock greenstone with small amounts of slate, graywacke, and quartzice. Sice of principal interest of prospectors in general area. 
(Copper R. bars)

Prince Willam Sound district
Gold

Cordova (11.5-15.3, 4.3-7.0) approx. $60015^{\prime}-60024^{\prime} \mathrm{N}, 145015^{\prime}-145040^{\prime} \mathrm{W}$ approx.

Sumary: Bars off Copper R. delta contain fine gold dertued from Copper R. drainage basin. Samples contained as much as 0.250 ppro gold. Pete Dahl Bar of this report (below) is near Copper Sands of most maps.

Reimnitz and Plafker, 1976 (B 1415), p. 9-10 -- Bars off mouth of Copper R. contain Eine gold. Samples from 2 bars (Green Island Bar and Pece Dahl Bar) contained Erom 0.003 to 0.250 ppm gold. Gold and ocher heavy minerals derived from Copper $R$. drainage basin rather than brought from east by longshore drift; very lictle gold east of main channel of river. Pere Dahl Bay appears to be as good as (or better chan) Yakataga beaches [Bering Glacier quad.] as a place for beach placer mining. 
Cordova Copper co.

Prlnce William Sound district MF-392, loc. 23

\section{Copper}

Cordova $(11.0,10.0)$ approx. $60^{\circ} 34^{\prime} \mathrm{N}, 145043^{\prime} \mathrm{W}$ approx.

Summary: Alcered and fractured amygdaloidal basalt of Orca Gp. carries copper minerals, as do stringers of quartz-epidote rock. Copper minerals are chalcopyrite, bornite, chalcocite, native copper, cuprite, and malachite. Minor development, 1905-09 and 1917. No commercial production, but native copper was exhibiced at an exposition in 1909. Includes references to (Fleming Spit).

Grant, 1906 (B 284), p. 84 - Irregular stringers of quartz-epidote rock in crushed amygdaloldal basalt. Chalcocite in stringers and in nonepldotized country rock. Native copper reported. Two small prospect holes in 1905.

Grant, 1910 (B 442), p. 165 - Company exhibiced large peices of nacive copper at Alaska-Yukon exposifion, 1909.

Granc and higgins, 1910 (B 443), p. 54 - Copper minerals are chalcopyrite, bornite, native copper, cuprite, and ralachite. p. 70 - Country rock is alcered, Eractured anggdaloids. Same daca as on p. 54.

Johnson, 1919 (B 692), p. 149 -- Development, 1917; 2 cunnels about 250 ft. apart vertically being driven; open cuts on outcrop of ore body.

Mackevert and Holloway, 1977 (OF 77-169A), p. 15, loc. 17 -- Reference to Grant and Higgins, 1910 (B 443). Country rock aragdaloidal basalt of Orca Gp. 
Dickey Copper Co.

Prince William Sound district MF-392, loc. 20
Copper, Gold, Zine

Cordova $(5.0,13.4)$

$60046^{\prime} \mathrm{N}, 146025^{\prime} \mathrm{W}$

Summary: Councry rock is graywacke, argllice, and slate of Orca Gp.; no greenstone or ocher igneous rock. Shear zone contains chalcopyrite, pyrite, sphalerite, pyrrhorite, and gold in quartz and calcice gangue. Sulfides appear to have preferentially replaced cercain (possibly originally limy) beds. Some postmineralization movement. 1,000 or more feet of underground workings. propercy active fromabout 1907 to about 1917; some ore (amount not known) shipped, 1914-17. Includes references co: Irish Cove, Mason \& Gleason.

Brooks, 1912 (B 520), p. 27 - Some work done on property by Threeman Mining Co. in 1911 .

Brooks, 1913 (B 542), p. 34 -- Development reported, 1912. Brooks, 1914 (B 592), p. 62 - Some ore mined and sledded to beach, 1913. Johnson, 1914 (B 592), p. 241-243 - Discovered, 1907. Devlopment until 1913 ; several hundred feet of underground workings on 3 levels; surface improvements; about 600 tons of ore mined, but not shipped; in ore bunkers (as of July, 1913).

Capps and Johnson, 1915 (B 605), p. 119-122 -- Chalcopyrite, pyrite, and quartz fill irregular, small, tubular wormlike channels in sedimentary rocks. Data on history and development of property essentlally as in Johnson, 1914 ( $B$ 592). Councry rock is series of interbedded graywacke, argillite, and siate (no igneous rocks); all sheared in a zone traced for $300 \mathrm{Ft}$. in workings; most individual shears strike between $N$ and $N 50^{\circ} \mathrm{E}$, apparently closely parallel to bedding; has been some postmlneralization movement. Ore in shear zone; consiscs of chalcopyrite, pyrice, sphalerice, and pyrchotice; considerable gold reported to be in parts of ore body; gangue minerals are quartz and calcite. Gold generally in parts of ore body that are lowest in chalcopyrite and high in sphaierite. In many places chalcopyrite appears to have preferentialiy replaced certain (possibly originally limy) beds.

Johnson, 1915 (B 622), p. 133-134 -- Development work, 1914; some ore said to have been found.

Johnson, 1916 (B 642), p. 141 -- Operated Nov.-Dec., 1915. Ore bunkers and wharf erected in Irish Cove.

Johnson, 1918 (B 662), p. 184 -- Ore shipped, 1916.

P. 187 -- 500-600 fi. of underground work done, 1916. Several hundred cons of ore shipped.

Johnson, 1919 (B 692), P. 144 -- Ore shipped, 1917.

p. 149 -- Propercy not known to have operated, 1917 , buc ore shipment said to have been made.

Brooks, 1912 ( $B$ 714), p. 22 - Deposit in shear zone in slate and graywacke: slace more crushed than graywacke. 
Dickey Copper Co. -- cont.

Moffit and Fellows, 1950 (B 963-B), p. 62 -- Most of daca from Capps and Johnson, 1915 ( 8 605). Abouc 600 tons of ore mined, but not shipped, 19l3. Ore consists of chalcopyrtie, pyrite, sphalerice, and pyrrhotite in shear zone in graywacke, argillite, and slare; no greenscone. Ore carries considerable gold.

Mackevett and Holloway, 1977 (OF 77-169A), p. 14, loc. 14-meferences to Capps and Johnson, 1915 (B 605) and Moffit and Fellows, 1950

( $8963-B)$. Country rock part of Orca Gp. 
Ellamar (Mining Co.)

Prince William Sound discricc

$M F-392$, loc. 4
Copper, Gold, Lead, Silver, Zinc

Cordova $(2.55,15.7)$

$60^{\circ} 54^{\prime} \mathrm{N}, 146^{\circ} 42^{\prime} \mathrm{W}$

Sumary: Strata-bound submarine volcanogenic deposit in flysch of Tertiary Orca Gp. near tholeiste. Principal ore body (considered to have been mined out) was a lenticular mass extending from surface Gwash at high tide) to depth of $530 \mathrm{ft}$. Where it pinched out; cross section on 200-ft. level was an ellipse with axes of 240 $\mathrm{ft}$. and $90 \mathrm{ft}$. Hanging wall part of deposit was a solid mass of pyrite separaced from underlying copper -sulfide ore by a 2-fC.thick body of black slate. Ore minerals were chalcopyrite, cubanite, pyrite, pyrrhotite, sphalerite, and galena; carried gold and silver, particularly in sphalertte-rich ore. Sraked in 1897 and operaced until mine was closed in 1920. One of two major copper mines in district; produced about 100 million pounds of copper and byproducr gold and silver (amounts not known). Pyrtle supplied as smelter feed. Developed by workings on several levels (deepest $600 \mathrm{ft}$. ) and inside coffer dam that allowed stoping to surface. Methane encountered in raises driven in slate in hanglng wall to obtain macerial to backfill scopes. Includes references to Gladhaugh.

Schrader, 1900 , p. 418-419 -. In 1898 a deposit about $300 \mathrm{ft}$. wide was being worked. Deposic known as early as 1895; staked in 1897. Country rock is gray arkose cut by a diabase dike, which "seems to have something to do with mineralization of the ore deposit."

Deposic exposed only ac low tide. Ore largely chalcopyrite and tetrahedrite with some bornite and epidoce and much marcasice.

Schrader and spencer, 1901, p. 89 -- Country rock is folded and sheared black shales. Velis is practically solid mass of copper and iron pyrites; $125 \mathrm{ft}$. wide where exposed; excends known discance of more chan $300 \mathrm{ft}$. along strlke. North wall strikes $N 450 \mathrm{~W}$ and dips $300 \mathrm{~N}$; south wall dip is considerably steeper. Vein has small inclusions of country rock, some calcite lenses, and a little bornite. Sample assayed $5.4 \%$ copper and 0.1 oz. gold a ton. Shaft being sunk in 1900 ; plan to crosscur co vein at depth of $150 \mathrm{ft}$.

Grant, 1906 (B 284), p. 81-82 - Staked in 1897. In 1905 shipped about $\mathrm{L}, 500$ tons of ore per month during summer. 5 levels (deepest 500-ft. level); on 200-ft. level ore body has lens-shaped cross section 190 $\mathrm{ft}$. Long and $80 \mathrm{ft}$. wide. Ore body consists of chalcopyrite, pyrice, pyrchotite, and varying amounts of slate country rock; mainly massive with a few calcitemfilled cracks. Countey rock much fractured and slickensided. 1905.

p. 87 -- Only producing copper mine in Prince Hilliam Sound in

Brooks, 1907 (B 314), p. 27 - Ore shipped, 1906. Mine said to ahve reached orh level at $600 \mathrm{ft}$. depth 
Ellamar (Mining Co.) -- cont.

Moffit, 1908 (B 345), p. 178 - Partly idle, 1907 (1abor trouble); shaft sunk to 600-ft. Level and $650 \mathrm{ft}$. of drifts rum.

Grant and Htggins, 1909 (B 379), p. 87-88 - Staked in 1897. Making regular shipments of ore, 1908.

p. 94-95 -- Output decreaged, 1908; lower grade macerial outside of poorly defined ore shoot being mined. Ore body pinched out between 500-ft. and 600-ft. levels. Prospecting for other ore bodies by diamond drilling along strike of lens being mined.

Brooks, 1910 (B 442), p. 32 -- Began shipping ore in 1901.

p. $39-$ Mining, 1909.

Grant, 1910 (B 442), p. 164 - Dam co keep out sea wacer being constructed to allow mining from 100-ft. level co surface, 1909.

Grant and Higgins, 1910 (B 443), p. 52-53 -- Staked in 1897. One of 2 mines in Prince William Sound that made regular shipmenrs of copper ore. Crystals of pyrize occur rarely.

p. 56-57 - Ore body is a lens-shaped mass with marimum and minimum horizontal axes of $190 \mathrm{ft}$. and $80 \mathrm{ft}$. Unmetamorphosed diabase dxke "may have played an important part in the formation of the ore body...."

p. 59-61 -- Essentially the same data as in Grant and Higgins, 1909 (B 379), p. 94-95. In 1909-10 coffer dam being built so ore between 100-ft. level and outcrop (under water at high tide) can be mined.

p. 78 -- Small amounts of sphalerite occur with copper minerals.

Brooks, 1911 (B 480), p. 31-32 - Coffer dam completed and some ore shipped, 1910 .

Brooks, 1911 (B 480), p. 81 -- Data from Grant and Higgins, 1910 (B 443). Brooks, 1912 (B 520), p. 27 -- Ore shipped in 1911 was from upper level. Capps and Johnson, 1913 (B 542), p. 97, L00-102 -- Preliminary to Capps and Johnson, 1915 (B 605).

Brooks, 1914 (B 592), p. 62 - Operated at full capacity, 1913.

Johnson, 1914 (B 592), p. 240-241 -- Data on mining merhods and surface plane. Average of 40 men worked throughout 1913.

Capps and Johnson, 1915 (B 605), p. 13-14-- Staked, 1897. Ore Eirst shipped in 1900 and regularly since then.

o. 51 - Ore as much as $600 \mathrm{ft}$. below sea level. Mine produced Ln 1912 .

p. 52-55, 57-61 -- References to and quotations from older reports.

p. 62-64 -- Ore deposit in shear zone that parallels bedding of councry rock; has been slight postmineralization movement in shear zone.

p. 71-72 -- Tiny veins of chalcopyrite with a little sphalerite cut earlier sphalerite. Very little copper in a massive pyrite lens. p. 87-92 -- Largely descriptions of workings and mining methods as of 1913; about 4,000 ft. of delfts and crosscuts on 8 levels plus stopes becween several levels. Ore body is a lenticular mass with 
Ellamar (Mining Co.) -- cone.

elliptical cross section on 200-ft. level with major axis of $240 \mathrm{ft}$. and minor axis of $90 \mathrm{fr}$., strikes about $\mathrm{N} 35^{\circ} \mathrm{W}$, dips $80^{\circ} \mathrm{NE}$, pitches steeply $S E$, and appears co conform to bedding of graywacke and slate country rock. Sulfides are chalcopyrice, pyrrhotite, sphalerite, and pyrice; gold and silver associated with sphalerice (specimens of sphalerite have assayed as much as $\$ 90$ [about $4.35 \mathrm{oz}$.$] a con gold).$ Galena prabably present; lead in assays. Gangue is quartz, calctte, and fragments of country rock. Pyrite earliest sulfide. Sulfides impregnated and replaced shatcered councry rock (including some limestone and limy beds) and first-deposited pyrtte.

Brooks, 1915 (B 622), p. 45 -- Copper ore shpimenes at normal race, 1914. Johnson, 1915 (B 622), p. 131 -- Ore shipments, 1914.

p. 133 - Enctre sulfide body being mines, 1914; mine is a large producer of copper and gold; smaller amouncs of silver. Developmenc was between 400-ft. level and surface; sorue workings in slate country rock.

Johnson, 1916 (B 642), p. 138 -- Large shipments as usual, 1915.

p. 140 - Work continued, 1915. Ralses in slate country rock reported to have encountered explosive gases.

Smich, 1917 (BMB 142), p. 39 -- Mainly data on mining methods.

Smith, 1917 (BMB 153), p. 44-45 -- Mainly data on mining methods and equipment. Methane encountered in raises in graphicic slace of hanging wall being driven to provide material for backfilling stopes.

Brooks, 1918 (B 662), p. 44 - One of largest copper producers in Prince William Sound, 1916.

Johnson, 1918 (B 662), p. 184-186 -- Mining, dlamond drilling, and surface improvements, 1916 .

Johrson, 1919 (B 692), p. 144 - Ore shipped, 1917.

p. 147 - Operated Eor nearly all of 1917. Considerable surface improvements and some diamond drilling.

Marcin, 1919 (B 692), p. 31 -- Operated on about the usual scale, 1917.

Marcin, 1920 (B 712), p. 33 - Operated at reduced capacity (shortages of labor and shippling space), 1918 .

Brooks, 1921 (B 714), p. 22 -- Ore in shear zone in slate; ore body is lenticular and may have been formed by replacement of calcareous lens in slate.

Brooks and Martin, 1921 (B 714), p. 69 - Mine worked chroughout 1919.

p. 77 -- Work in 1919 on about the same scale as in the past.

Brooks, 1922 (B 722), p. 20 -- Mine closed, 1920.

Bain, 1946 (IC 7379), p. 33 -- Was one of the two major copper mines in Prince William Sound. Considered worked out.

Mofflc and Fellows, 1950 (B 963-B), p. 50 - Ellamar and Lacouche [Seward quad.] produced nore than $96 \%$ of the $214 \mathrm{milli}$ on pounds of copper Erom Prince William Sound.

p. S5-56 - Most of data from Capps and Johnson, 1915 (B 605). Mine reported to have closed because ore was too low grade to be proficable under 1919 conditions. Galena probably presenc; smelter returns showed lead. 
Ellamar (Mining Co.) -- cont.

Moffit, 1954 (B 989-E), P. 228 -- Claims staked, 1897.

p. 297-298 - Most productive mine in northeastern part of Prince Willam Sound. Produced copper, gold, and silver and pyrite for smelter use. Ore body was a steeply pitching lenticular mass of sulfides in slate and graywacke of Orca Gp.; reported to have pinched out at depth of $530 \mathrm{ft}$. Lens of solid pyrite formed hanging wa11; underlying ore (separated from pyrite body by 2-fi.-chick body of black slate) consisted of parallel lenses of chalcopyrite, pyrthotite, and sphalerice. Most of gold and silver in sphalerite. Pyrite oldest sulfide; sphalerite youngest.

p. 302 -- Same as Moffit and Fellows, 1950 (B 963=B), p. 50.

Berg and Cobb, 1967 (B 1246), P. 69 -. Data sumarized or quoted from Moffic, 1954 (B 989-E).

Koschmann and Bergendah1, 1968 (P 610), p. 32 -- Copper ores ac Ellamar and Latouche [Seward quad.] carry considerable amouncs of gold; amount produced could not be decermined.

Mackevetc and Holloway, 1977 (OF 77-169A), p. 14, Loc. 4-- References to Capps and Johnson, 1915 (B 605) and Moffit and Fellows, 1950 (B 963-B). Sulfide-rich lenses in Orca Gp. graywacke and slace near submarine basalt. Mine produced about 100 milifion pounds of copper and some byproduce gold. Ore consiscs of chalcopyrice, cubanice, pyrrhotite, pyrite, sphalerite, and galena.

Winkler and others, 1977 (C 75l-B), p. 844-B45 - One of che principal copper deposics of Prince "William Sound. Recent regional studies indicace that the deposits in the district are mostly strata bound and are syngenetic and related to recurring tholelicic volcanism. Ore in thlck pyritic sandstone and shale on margin of choleiite. Mackevert and ochers, 1978 ()F 78-l-E), p. 15 -- Data on production same as in many older reports. Deposits of area [presumably including Ellamar] are submarine volcanogenic in origin. Area underlain by flysch and mafic volcanic rocks of Teriary Orca Gp. 
Falck

Prince William Sound discrice

$M F-392$, loc. 12
Copper, Zine

Cordova (3.85, 15.2$)$

$60^{\circ} 52^{\prime} \mathrm{N}, 146033^{\prime} \mathrm{W}$

Summary: Sheat zones in greenstone and other rocks of Orca Go. contain quarcz, calcite, chalcopyrice, pyrrhotice, sphalerice, and (on surface only) small flakes of nacive copper. No more chan assessment wark reported.

Capps and Johnson, 1915 (B 605), p. 72 -- Small flakes of native copper on weathered outcrops of lode.

p. 103-104 - Claims located in about 1900; only assessmenc work has been done on them; short sdit and open cuts. Country rock mainly greenstone; some black slate and a little graywacke. Generally northeastward-striking steeply dipping shear zones contain quartz, calcice, chalcopyrite, pyrrhotite, sphalerice, and (on surface showlings only) secondary naive copper.

Mackevett and Holloway, 1977 (OF 77-169A), 0. 14, loc. B -- Reference to above. Country rock part of Orca Gp. 
Fidalgo (MIning Co.)

Prince Willtam Sound districr

$M F-392$, LoC. 21
Copper, Gold

Cordova $(6.05,13.95)$

$60048^{\prime} \mathrm{N}, 146018^{\prime} \mathrm{W}$

Summary: Discovered in 1905; property active until as recently as 1922; mose production (total not known, but was more than a few hundred tons), 1913-19. Mine consisced of several hundred (probably more than $\mathrm{l}, 000) \mathrm{Ec}$. Of workings on 2 levels. Country rock mainly greenstone of Orca Gp.; some interbedded sedimentary rocks. 2 ore bodies in shear zone 20-30 Et. Wide; ore consiscs of chalcopyrite, pyrice, pyrrhotite, and as much as about 0.05 oz. a con gold; average copper content of ore shipped in 1913 was a little more than $8 \frac{1 \%}{2}$. Ore shoocs formed by open-space filling and replacement of greenstone. Includes references to: Mackintosh,. MeIncosh.

Grant and HiggLns, 1909 (B 379), p. 96 - Tunnel driven 450 ft. along well-defined shear zone. 2 lens-shaped ore bodies, each about $5 \mathrm{ft}$. by $50 \mathrm{Fr}$. In cross section, were encountered. Ore chiefly chalcopyrice. Small crosscut showed $20-i n$. vein of nearly solld chalcopyrite. Some surface seripping on shear zone. Some ore ready to ship, 1908.

Grant and H1ggins, 1910 ( $B$ 443), p. 63 - Same as above.

Brooks, 1913 (B 542), P. 34 - Development, 1912. Has been about $600 \mathrm{ft}$. of underground work.

Brooks, 1914 (B 592), p. 62 -- Ore shipped, 1913.

Johnson, 1914 (B 592), p. 240-242 m- Discovered, 1905. As of 1913 developments were several hundred feet of underground workings on 2 levels and excensive surface improvements. Several ore shipments in 1913.

Capps and Johnson, 1915 (B 605), p. L13-117 -- Historical data about the same as in earlier reports; detalls of surface plant. Country rock is greenstone (some ellipsoldal) and interbedded sedimentary rocks (many now metamorphosed); schist apparently thrust over less-metamorphosed rocks. Ore in 2 subparallel zones in a shear zone 20-30 ft. wide chat 5 crikes norcherly and dips 550-750E. Metalkic minerals in ore include chalcopyrite, pyrice, and pyrrhotice; gold contenc from $\$ 0.50$ co $\$ 1.00$ a con [gold ar $\$ 20.67]$. Average copper concent of ore shipped was a little over $8 \frac{1}{3} \%$. Sulfides replaced sheared greenstone and possibly filled open cracks.

Johnson, 19L5 (B 622), p. 134 -- Some development, but no ore shipped in early 1914. New ore shoot found $600 \mathrm{ft}$. Erom portal of main tunnel.

Johnson, 1916 (B 642), p. 138, 141 - Small crew worked pare of 1915; several hundred tons of ore shipped to Tacoma smelcer.

Smith, 1917 (BMB 142), p. 39 - Chalcopyrite ore in shear zone in slate, graywacke, and greenstone.

Smith, 1917 (BMB 153), p. 45-46 -- Chalcopyrite ore in shear zone (in slace, graywacke, and greenstone) that strikes $1300 \mathrm{~W}$ and dips $670 \mathrm{NE}$. Developed by 2 drifts with ralses to surface. 
Fidalgo (Mining Co.) -- cont.

Johnson, 1918 (B 662), P. 184 -- Ore shipped, 1916.

p. 286 - Shipped a few hundred cons of ore, 1916. Abouc 250

$\mathrm{ft}$. of cunnels driven and water-power plant installed.

Johnson, 1919 (B 692), p. 144 - Ore shipped, 1917.

p. 148 - Considerable development and some ore shipped, 1917.

Martin, 1919 (B 692), p. 31 -- Mackintosh was a produccive copper mine, 1917.

Marcin, 1920 (B 712), p. 33 m Underground developmenc, but no ore shipped, - 1918.

Brooks, 1921 ( 8714 ), p. 22 - In shear zone in incerbedded slate and graywacke; slace more crushed than graywacke.

Brooks and Marein, 1921 (B 714), p. 69 - Some ore produced incidental to development, 1919.

p. 77 -- Development work, 1919.

Brooks, 1922 (8 722), p. 21 -- Development work, 1920.

p. 40 -- Some ore mined, but not shipped, in course of driving $245 \mathrm{ft}$. of raise and drift, 1920.

Brooks, 1923 (B 739), p. 24 - No work, 1921.

Brooks and Capps, 1924 (B 755), p. 29 - 3-ft. adie driven, 1922.

Moffit and Fellows, 1950 (B 963-B), p. 61-62 -- Most of data from Capps and Johnson, 1915 ( 8 605).

Mackevett and Holloway, 1977 (OF 77-169A), p. 15, loc. 15 -- References to Capps and Johnson, 1915 ( $B$ 605), and Moffit and Fellows, 1950

( 8 963-B). Ore in shear zone that cuts Orca Gp. (mainly greenscone). 
Flelder \& Hemple

Prince William Sound district MF-392, Loc.?

\section{Copper}

Cordova $(3.2,15.5)$

$60^{\circ} 53^{\prime} \mathrm{N}, 146^{\circ} 37^{\prime} \mathrm{W}$

Summary: Shear zone in ellipsoldal greenstone and assoclaced slace of Orca Gp. concaias small masses of pyrice wich a liccle chalcopyrice, pyrrhotite, and quarcz. Abour $300 \mathrm{ft}$. of underground workings, mainly in barren rock. Work done in early $1900^{\prime} \mathrm{s}$.

Grant and Higglns, 1909 (8 379), p. 94 -- 2 claims practically surrounded by those of Reynolds-Alaska Development Co. About 200 ft. of underground workings and small surface excavations that exposed chalcopyrice stringers in sheared greenstone. Some ore ready for shlpment, 1908.

Capps and Johnson, 1913 (B 542), p. 114-115 -- Preliminary co Capps and Johnson, 1915 (B 605).

Capps and Johnson, 19l5 (B 605), p. 57 -- Reference to Grant and Higgins, 1909 (B 379).

p. 98 -- Shear zone in ellipsoidal greenstone and a licele shate strikes $N 45^{\circ} \mathrm{E}$, dips $65^{\circ} \mathrm{N}$, and $1 \mathrm{~s} 25-30 \mathrm{ft}$. wide; contains small masses of flne-grained pyrice with a little chalcopyrice, pyrrhotice, and quartz. Most of the approximate $300 \mathrm{fr}$. of workings in apparencly barren materlal.

Mackevetr and Holloway, 1977 (OF 77-169A), p. 14, loc. 6-- Reference to Capps and Johnson, 1915 (B 605). Country rock part of Orca Gp. 
Galena Bay (Mining Co.)

Prince Whllian Sound districe $M F-392$, locs, 9,10
Copper, Gold, Zinc

Cordova (3.1-3.45, 15.4-15.5)

$60^{\circ} 33^{\prime} \mathrm{N}, 146035^{\prime}-146036^{\prime} \mathrm{W}$

Summary: Country rock is mainly sheared greenstone (some ellipsoidal) of Orca Gp. west of Landlock thrust Eault (in lower plate). Ore is chalcopyrite, pyrrhotice, pyrite, and sphalerice in small replacement bodies and fracture fillings; a few dollars worth of gold per ton in some of ore; gangue mainly quattz and calcite. Several chousand feet of underground workings, surface excavations, and excensive surface loprovements that were never completed. Development between about 1905 and 1914 ; no producclon reported. Includes references to: (Galena Bay), (Vesuvius Valley).

Grant, 1906 (B 284), P. 83 - Veins along shear zones in greenstone carry pyrice, pyrrhotice, and chalcopyrice; sulfides also disseminated in wall rock. Has been stripping; several short tunnels were driven in greenstone. Longest cunnel driven $300 \mathrm{ft}$. to intercept a large shear exposed at surface has not reached th yet, 1905.

Moffic, 1908 (B 345), p. 178 -- Aerial tram and ore bunkers being buile. 1907.

Grant and Higgins, 1909 (B 379), p. 93 - Has been much work on surface plant. In August, 1908, cunnel being driven to intersect shear zone exposed on surface was more than $1,500 \mathrm{fc}$. 1ong.

Grant, 1910 (B 442), p. 164 - Tunnel extended to length of about 1,800 ft., 1909. Also some diamond ditlitng, which intersected a body of ore about $30 \mathrm{ft}$. thick.

Grant and Higgins, 1910 ( $B$ 443), p. 59 - Data essentially as in Grant and Higgins, 1909 (B 379) and Grant, 1910 (B 442).

Capps and Johnson, 1913 (B 542), p. 112-114 - Preliminary to Capps and Johnson, 1915 (B 605).

Capps and Johnson, 1915 (B 605), p. 98-102 - Discovered in 1899. In 1913 exploration and development consisted of about 2,600 $\mathrm{ft}$. of underground workings, numerous surface excavarions, some diamond drilling, and considerable surface improvements. The country rock is mainly greenstone (some ellipsoidal), with small amounts of graywacke and slate. Mineral deposics are in shear zones west of the landlock thrust fault [in lower place] and consist of replacemenc bodies and fracture fillings of sulfides with some quartz and calclce gangue; all sulfide bodies are small. Sulfides are chalcopyrite, pyrrhotite, pyrice, and sphalerice. One quartz vein contains small amounts of sulfides and $\$ 3-\$ 4$ a con gold $[$ at $\$ 20.67]$.

Johnson, 1915 ( В 622), p. 133 - Claims surveyed Eor pacent, 1914.

Johnson, 1916 ( 8 642), p. 140 - Assessment work only, 1915.

Smith, 1917 (BMB 142), p. 40 - Assessment work only, 1915.

Smith, 1917 (BMB 153), p. 46 -- Assessment work only, 1916.

Moffit and Eellows, 1950 (B 963-B), p. 53-54 - Many of data from Capps and 
Galena Bay (Mining Co.) -- cont.

Johnson, 1915 (B 605). Exploration between 1905 and 1914, when claims were patented. Total of several thousand feet of underground workings and surface excavations on several claims. Surface plant never complecely installed and no ore produced.

Mackevect and Holloway, 1977 (OF 77-169A), $\beta .14$, loc. $T$-- References to Capps and Johnson, 1915 (B 605) and Moffit and Fellows, 1950

(B $963-B$ ). Bedrock is greenstone of Orca GP. 
Summary: Surface and subsurface developments at a prospect on body of chalcopyrite ore $\mathrm{ln}$ a vein said to be $4 \mathrm{ft}$. wide and exposed iso feet above the cunnel. Expect co ship ore in 1911 . May refer to a mine on Galena Bay, on Landlocked Bay, or on Glacier I. [Seward quad.].

Brooks, 1911 (B 480), p. 31 - "The Glacial Igland Copper Co. is said to have opened a body of high-grade chalcopyrite ore by a tunnel 170 Feet in length. The vein is said to be 4 feet wide and to be exposed 150 feet above the tunnel. A small bunker has been built and che managers report chat some shipments will be made in 1911." 
(Hartney Bay)

Prince William Sound district

\section{Copper}

Cordova $(9.45-9.65,8.5-8.55)$

$60^{\circ} 29^{\prime} \mathrm{N}, \quad$ 145053'-145054'W

Sumary: Old copper prospects on shear zones in volcanlc unit of lower Tertiary Orca Gp.

Winkler, 1973 (MF-531) -- Open workings of inactive, unparented copper prospects. In volcanic unit of Orca $\mathrm{Gp}$. (Lower Tertiary).

Mackevett and Holloway, 1977 (OF 77-169AO, p. 14, 10C. 25 -- Reference to above. On a shear zone. 
Head-of (-the) -Bay

Prince William Sound districe $M F-392$, loc. 25

\section{Copper}

Cordova $(12.25,11.5)$

$60^{\circ} 39^{\prime} \mathrm{N}, 145034$ ' W

Summary: Copper prospect in slate of che Orca Gp. near a body of Tertiary granite. Prospecting in 1909. No data on size or mineralogy of deposit; probably safe to assume that some copper mineral is present.

Grant, 1910 (B 442), p. 165 - Prospecting, 19 LO. Prospect is close to contact between a diortte mass and graywacke and slate country rock.

Grant and Higgine, 1910 ( $B$ 443), p. 70 -- Essencially the same as above. Mackevect and Holloway, 1977 (OF 77-169A), p. 15, Loc. 19- Reference to Grant and Miggins, 1910 (B 443). Prospect in slate of Orca Gp. near Terclary granice. 
Hemple (Copper Co.)

Prince William Sound district $M F-392,10 \mathrm{C} .14$
Copper, Gold, Silver, Zinc

Cordova $(3.8-4.0,15.0-15.1)$

$60^{\circ} 51^{\prime}-60^{\circ} 52^{\prime} \mathrm{N}, 146^{\circ} 32^{\prime}-146^{\circ} 33^{\prime} \mathrm{W}$

Sumary: Sulfides replaced sheared country rock and Eilled fractures in a shear zone in greenstone of Orca Gp. Pyrrhotite principal sulfide; others are pyrite, chalcopyrite, and sphalerice; as much as 0.32 oz. a ton each of gold and silver. More than 1,300 fi. of undergrond workings and many surface excavacions, but no recorded production. Last report of actlvity was in 1924 . Includes reference to Hemple Mining Co.

Grant and Higgins, 1909 (B 379), p. 95 -- 2 tunnels ( 125 and 400 fr. long) and surface excavatlons. Chalcopyrite in greenstone. Some sorted ore on dump, 1908.

Brooks, 1912 (B 520), p. 27 - Reported that at end of 1911 total of 2,000 $\mathrm{ft}$. of cunnel had been driven.

Capps and Johnson, 1913 (B 542), p. 118-119 -- Preliminary to Capps and Johnson, 1915 (B 605).

Cappa and Johnson, 1915 (B 605), p. 57-58 -- Quotation from Grant and Higgins, 1909 (B 379).

p. 106-107 -- Deposit in shear zone (average width $24 \mathrm{ft.}$ ) in greenstone, slace, and graywacke; shear zone strikes $\mathrm{W}$ to $\mathrm{N} 55^{\circ} \mathrm{W}$ and dips about $60^{\circ} \mathrm{N}$; has been traced for over $1,500 \mathrm{Et}$. in surface excavations, shallow shafes, and adics (abour $1,300 \mathrm{ft}$. of underground workings). Metallic minerals irregularly distribuced; occur as stringers and other bodies of solid sulfides and in calcite bodies in sheared greenstore. Ore bodies are mainly replacements of sheared councry rock and fracture fillings. Pyrchotite is the most abundant sulfide; ochers are chalcopyrite and sphalerice. Average assays of mineralized parts of shear zone are $3 \%-6 \%$ copper; one assay of an old sample showed $6 \%$ copper, and $\$ 1.20$ in gold and $\$ 1.50$ in silver; solid sulfide lenses reported to contain about 6\% copper.

Johnson, 1915 (B 622), p. 133 - A litcle development work, 1914.

Johnson, 1918 (B 662), p. 186 - Drove $150 \mathrm{ft}$. of tunnel in 1916.

Johnson, 1919 (B 692), p. 148 - Crosscut driven 110 Et. in 1917; struck a slightly mineralized shear zone that strikes $N 700^{\circ}$ and dips $E$ and is at leasc $8 \mathrm{ft}$. wide.

Smich, 1926 (B 7B3), p. 21 -- Prospecting and/or development reported, 1924. Moffit and Fellows, 1950 (B 963-B), p. 59 -- Data Erom Capps and Johnson, 1915 (B 605) summarized [not specificaliy ciced].

Mihelich and Wells, 1957 (RI 5320), p. 6 -- Was active prospecting, buc no ore was shipped.

p. 13 - Map of prospect. Samples assayed contalned as much as $1.1 \% \mathrm{C}_{1}, 1.3 \% \mathrm{zn}, 0.32 \mathrm{oz}$. a con each of gold and silver.

p. 18 - Explored by 2 tunnels (total lengch 1,340 Et.). In a shear zone chat strikes eastward and dips abouc $60^{\circ} \mathrm{N}$. Contains sulfide lenses as much as $6 \mathrm{it}$. thick. Sulfides mainly pyrite and pyrm 
Hemple (Copper Co.) -- cont.

Thotite. Country rock greenstone, slate, and graywacke.

Mackevett and Holloway, 1977 (OF 77-169A), p. 14, loc. 10 - References co Capps and Johnson, 1915 (B 605) and Mihelich and Wells, 1957

(RI 5320). Country rock mainly greenscone of Orca Gp. 
Hoodoo

Prince William Sound district

$M F-392,10 C .15$
Copper, Gold, Zinc

Cordova $(3.85,14.85)$

$6005 L^{\prime} N, 146033^{\prime} \mathrm{W}$

Summary: Shear zones in greenscone of Orca Gp. concain chalcopyrice, pyrrhotice, sphalerite, and as much as abouc an ounce of gold a ton; native copper on iron-stained outcrops. Located in 1904 ; being worked in 1912. About $285 \mathrm{ft}$. of underground workings and considerable surface stripping. No record of production.

Capps and Johnson, 1913 (B 542), p, 122-123 -- Premininary to Capps and Johnson, 1915 (B 605).

Capps and Johnson, 1915 (B 605), p. 111 -- Located in 1904. Considerable surface seripping and abour $285 \mathrm{ft}$. of underground workings, $252 \mathrm{ft}$. of which is in slide rock. Country rock greenstone; northwescerly strlking shear zones that dip from $55^{\circ} \mathrm{N}$ to nearly vertical contain as much as $3 \mathrm{ft}$. of ore. Chalcopyrite, pyrrhotite, and sphalerice in quartz gangue in shear zones; assays of $\$ 10-\$ 22$ [about $0.48-$ $1.06 \mathrm{oz}$.$] a ton in gold reported. Native copper on iron-stalned$ ouccrops. Work in $19 \mathrm{~L} 2$.

Mackevert and Holloway, 1977 (OF 77-169A), p. 14, 10c. ll - Reference co above. In volcanics of Orca $\mathrm{Gp}$. 
Ibach

Rrince Willian Sound district $M F-392,100.26$.
Copper

Cordova (13.7, 11.7 ) approx. $60^{\circ} 39^{\prime} \mathrm{N}, 145025^{\prime} \mathrm{W}$ approx.

Sumary: Veins in Orca Gp. rocks contain native copper.

Grant and Higgins, 1910 ( $B$ 443), p. 70 -- Prospects have been located near 5 cotc Glacier on veins carrying narive copper. [Index map shows claims with Ibeck (misspelling of Ibach) as one of the owners in this axea.]

Rossman, D. L., 1952, field notes - Joe Ibach cold Rossman abouc a copper prospect aboue 22 miles Erom Copper River Rallroad, Mile 13 [must be closet than that to railroad]. Vein 22-20 Ec. wide and possibly 2 mi. long. Recorded in Valdez in 1906 as The Sure Thing.

Berg and Cobb, 1967 (B 1246), p. 71 -- Located early in cencury; near concact becween diorice and black slate.

Mackevect and Holloway, 1977 (OF 77-169A), p. 15, loc. 24 -- Reference to Grant and Higgins, 1910 ( $B$ 443). Natlve copper-bearing veins in Orca Gp. 
(Jack Bay).

Prince William Sound district

$M F-392,100.1$
Copper, Gold(?)

Cordova $(4.8,17.3)$

$60059^{\prime} \mathrm{N}, 146026^{\prime} \mathrm{W}$

Sumary: Small quartz veins in black slace contain chalcopyrite and pyrrhotite. As this occurrence is desceribed in a section on gold quartz veins, gold may be present even though such is not specifically stated.

Johnson, 1919 (B 692), p. 173 -- Small quartz vein 2 in. thick cuts black slate; strikes $N$ and dips $55^{\circ} \mathrm{W}$. Chalcopyrite and pyrrhotite are only metallic minerals observied. [Described in a section on gold prospects.]

[Mackevete and Holloway, 1977 (OF 77-L69A), p. 14, loc. I - Reference to same page as above. As plocted on maps and described in table is probably Orion claim, which I interpret (on the basis of newer maps) as being in Valdez quad.] 
Landlock(ed) Bay Copper Mining Co. Copper, Gold, Silver, Zinc

Prince William Sound district Cordova (3.85, 14.85)

$M F-392$, LOC. $15 \quad 60051^{\prime} \mathrm{N}, 146033^{\prime} \mathrm{W}$

Summary: Discovered, 1898. Most work between 1903 and 1916. Over 900 Et. of underground workings. Ore is chalcopyrite, pyrrhorite, sphalerite, and cubanite in quartz and calcite gangue in a curving shear zone in greenstone (a little incerbedded slace and ltmestone) of Orca $\mathrm{Gp}$. Samples assayed contained as much as $6.8 \% \mathrm{Cu}, 3.5 \% \mathrm{Zn}$, and traces of gold and silver. 928 cons of $4 \%$ copper ore (copper contenc abour 74,200 lbs.) shipped in 1916; a small shpiment in 1912 was also reported.

Capps and Johnson, 1913 (B 542), p. 97, 110-112 - Preliminary so Capps and Johnson, 1915 (B 605).

Brooks, 1914 (B 592), p. 62 - Development continued, 1913.

Johngon, 1914 (B 592), p. 421 -- 2 or 3 man doing underground development, 1913 .

Capps and Johnson, 1915 (B 605), p. 14 - Smal1 shipment of ore, 1912.

P. 51 -- Some production, 1912.

p. 96-97 -- Discovered, 1898; all underground work since 1903;

by 1912 included over $900 \mathrm{fc}$. Of workings. Deposic in shear zone in greenstone with a little interbedded slate and limestone. Shear zone strikes from $N$ to $N 760 \mathrm{~W}$ and dips from $30^{\circ} \mathrm{E}$ to $65^{\circ} \mathrm{N} ; 4-15 \mathrm{Et}$. Wide. Indluidual ore shoots as much as $30 \mathrm{ft}$. long and $7 \mathrm{ft}$. chick in places; formed by sulfide replacement of sheared councry rock. Sul fies lnclude chalcopyrice, pyrthorlce, sphalerice, and a few specks of an unidentified sulfide; gange quartz, calcite, slate, and green-

Johnsontopg15 (B 622), p. 133 - A litcle development work, 1914.

Johnson, 1916 (B 642), P. 141 - Development work reported, 1915; no ore known to have been shipped.

Smich, 1917 (BMB 142), p. 41 - Ore in shear zone. 2 crosscuts have intersected ore, on which winzes have been sunk.

Smith, 1917 (BMB 153), p. 48 -- Same as above.

Johnson, 1918 (B 662), P. 186 -- Assessment work only, 1916.

Johnson, 1919 (B 692), p. 148 - No work, 1917.

Moffit and Eellowes, 1950 (B 963-B), p. 57-58 -- Most of daca Erom Capps and Johnson, 1915 (B 605). Sulfides present were chalcopyrite, pyrrhotite, sphalerice, and a litcle chalmersice [cubanite]. The small amount of ore shipped was reported to contain $7 \frac{1}{2} \%$ copper.

Wihelich and Wells, 1957 (RI 5320), p. 5-6 -- By 1916 extensive Inscallations and underground developments had been completed at this and other mines in neighbortrood. In 1916928 tons of $4 \%$ ore containing 74,200 lbs. of copper was senc to smelter.

p. 11 -- Mine map. Assays of samples showed as much as $6.8 \%$ $\mathrm{Cu}, 3.5 \% \mathrm{Zn}$, and traces of gold and silver.

p. 17-18 -- Ore discovered, 1898. 928 tons of hand-sorced $4 \%$ copper ore shipped in 1916 . Ore occurs in small lenses of chalco- 
Landlock(ed) Bay Copper Mining Co. -- cont.

pyrice, pyrite, and pyrrhortte in shear zone in greenstone or graywacke with interbedded slate. Shear zone 4-ls ft. Wide. Localization and atticude of sulflde lenses appear to have been controlled by intersection of shear zone with north-dipplng faults. Ore lenses 25-100 fr. long and slightly more than a fooc wide. One of lenses partly stoped and also explored by a winze reported to be $25 \mathrm{ft}$. deep.

Mackevett and Holloway, 1977 (OF 77-169A), p. 14, loc. 11- References to Capps and Johnson, 1915 (B 605) and Mihelich and Wells, 1957 (RI 5320). In shear zone(s) in volcanics of Orca Gp. 
Lucky Scrike (Mining) Co.

Prince Willian Sound district MF 392, LoC. 28

\section{Gold}

Cordova $(15.65,8.5)$

$60028^{\prime} \mathrm{N}, 145012 \mathrm{~W}$

Sumary: In early 1900's and in about 1926-30 several rundred feet of workings were driven to explore quartz vein and ledge of brecciaced graywacke of Orca Gp. that was healed with quartz. Arsenopyrice and free gold present in ledge and adjacent country rock. Assays of samples showed as much as about $3.9 \mathrm{oz}$. gold a ton. Mill test of selected material said to have given higher yields. Includes reference to Lucky strlke Syndicate.

Chapin, 1913 (B 542), p. $79-3$ cunnels with reported cotal length of abour $400 \mathrm{Et}$; 2 on ledge $20 \mathrm{Et}$. wide consisting of brecciated graywacke healed with quartz and carrying considerable arsenopyrite and specks of gold. Assays reported to show $\$ 8-\$ 10$ a con [gold at $\$ 20.67]$. The other cunnel follows a vein between layers of gouge; some of veln sald to assay $\$ 80$ [about $3.90 z$.$] a con; average value$ $\$ 15$ [about 0.73 oz.] a ton. Mill test of individual stringers reported to have yielded at high as $\$ 100$ a ton; country rock adjacent to ledge contalns pyrite, arsenopyrite, and free gold; said to assay about $\$ 185$ a ton.

Smith, 1929 (B 797), p. 12 -- Revival of exploration, 1926.

Smith, 1932 (N 824), p. 23 - Continued exploracion, 1929. Crosscut 320 Ec. long, but is $36111420 \mathrm{ft}$. From estimared position of vein. Several bulldings that were burned in 1928 were reconstructed. Smith, 1933 (B 836), p. 22 -- A very little work done in 1930. Mackevect and Holloway, 1977 (OF 77-169A), p. 15, Loc. 22 - Reference to Chapin, 1913 (B 542). Country rock slace and graywacke of Orca $\mathrm{Gp}$. 
(Mckinley Lake)

Erince William Sound district
Gold

Cordova ( $15.6-15.65,8.3-8.75)$ $60^{\circ} 28^{\prime}-60^{\circ} 29^{\prime} \mathrm{N}, 145^{\circ} 12^{\prime} \mathrm{W}$

Summary: Quartz veins in sandstone and shale carry free gold. See also: Bear Creek Mining Co., Lucky Strike Mining Co., Mckinley Lake Mining Co.

Schrader and Spencer, 1901, p. 90 -- Quartz veins are both parallel and transverse to bedding of sandstone and shale. Large amount of visible gold in small quartz stringers on one claim. Ledges from a $f e w$ inches to several teet wide can be craced for long distances. Transverse veins carry no visible gold; sample from one contained $1 / 64$ oz. gold [a ton]. 
Mckinley Lake Mining Co.

Prince Whlliam Sound district

MF-392, 1.0C. 29
Gold

\section{Cordova}

$60^{\circ} 28^{\prime} \mathrm{N}, 145^{\circ} 12^{\prime} \mathrm{W}$

Summary: Quartz veins and graywacke of Orca Gp. concain pyrtte, arsenopyrite, and free gold. Ouccrop reported to have carried about $4.84 \mathrm{oz}$. a con gold; mineralized ledge reporced to have averaged about 0.48 oz. a ton gold. has been gold production; amount not known.

Chapin, 1913 (B 542), p. 79 -- Mass of quartz veins enclosing blocks of graywacke. Developed by 2 tunnels with aggregate lengch of over 600 Et. and several open cuts. Entire mass mineralized with pyrite, arsenopyrite, and Exee gold. Outcrop sald to have assayed $\$ 100$ [about $4.84 \mathrm{oz}$. ] a con; average for ledge reported co be $\$ 10$ [about $0.48 \mathrm{oz}$.$] a ton. Small mill was operaced for a number of years$ [no data on amount of production].

Mackevett and Holloway, 1977 (OF 77-169A), p. 15, loc. 22 -- Reference to above. Veins generally parellel co hosc slate and graywacke of orca Gp. [these data from Schrader and Spencer, 1901, p. 90; not clted]. 
McNaugheon \& Turner

Prince Willdam Sound district $M F-392,10 C .5$
Copper, Zinc

Cordova $(3.1,15.9)$

$60^{\circ} 54^{\prime} \mathrm{N}, 146^{\circ} 38^{\prime} \mathrm{W}$

Sumary: Shactered graywacke at or near contacts with greenscone healed by quarcz carrying chalcopyrtice and sphalerite.

Johnson, B. L., 1912-1917, field notes -- Small open cuts and a 70-ft. tunnel show shatcered graywacke at or near contacts with greenstone; healed by sulfide-bearing quartz; malachice staining. Sulfides include chalcopyrice and sphalerite.

Mackevet and Hol Loway, 1977 (OF 77-169A), p. 14, Loc. 5 -- Reference to above. 
Mogu 1

Prince W1lliam Sound digcrict

$M F-392,10 C .8$
Copper, Zinc

Cordove $(3.4,15.7)$

$60^{\circ} 54^{\prime} \mathrm{N}, 136^{\circ} 36^{\prime} \mathrm{W}$

Sumary: Chalcopyrite, pyrite, pyrrhotice, and sphalerite in irfegular masses in sheared greenscone of Orca Gp. Only minor development.

Capps and Johnson, 1915 (B 605), p. 98 -- Sulfide minerals (including chalcopyrice, pyrite, pyrrhorite, and sphalerite) in irregular masseg in sheared and shattered greenstone. Developed by shaft lo ft. deep and several open cuts.

Mackevete and Holloway, 1977 (OF 77-169A), p. 14, 1oc. 7 -- Reference to above. In sheared greenstone of Orca Gp. 
Montezuma

Prince William Sound district $\mathrm{MF}-392,10 \mathrm{c} .13$
Copper, Gold, Silver

Cordova $(3.7-3.85,15.0-15.15)$

$60^{\circ} 51^{\prime}-60^{\circ} 52^{\prime} \mathrm{N}, 146^{\circ} 33^{\prime}-146^{\circ} 34^{\prime} \mathrm{W}$

Sumary: Irregular lenses of pyrrhotite and/or pyrite in a shear zone In greenstone (one incerbed of slate) of Orca Gp. Sulfides replaced and impregnaced greenstone. Developed by about 400 ft. of underground workings and $900 \mathrm{ft}$. of stripping. May have been a smal1 ore shipment in 1916. Samples of a quartz vein contalined $0.18 \mathrm{oz}$. gold and $0.08 \mathrm{oz}$. silvet a con. Includes references to Buckeye.

Capps and Johnson, 1913 (B 542), p. $12 \mathrm{~L}$ - Preliminary ro Capps and Johnson, 1915 (B 605).

Jhonson, 1914 (B 592), p. 241 -- Underground developmenc work, 1913. Capps and Johnson, 1915 (B 605), p. 108-109 -- More than 350 it. of underground workings and stripping for $900 \mathrm{ft}$. along lode. Country rock greenstone wich a slate incerbed as much as $15 \mathrm{ft}$. thick. Shear zone that strikes $\mathrm{E}$ and dips $65^{\circ} \mathrm{N}$ is irregularly mineralized with lenses of chalcopyrice and pyrrhotite. Sulfides impregnated and replaced sheared country rock.

Johnson, 1915 (B 622), p. 133 -- Ore reported to have been found, 1914. Smith, 1917 (BMB 142), p. 43 - - Part of Three Man Mining Co. property. Srith, 1917 (BMB 153), p. 50 - Same as above.

Johnson, 1918 (B 662), p. 184, 186 -- A little ore shlpped from Buckeye group, 1916. One or two men worked in spring and summer.

Johnson, 1919 (B 692), P. 148 -- Only assessment work on Buckeye group, 1917.

Moffit and fellows, 1950 (B 963-B), P. 59 -- $370 \mathrm{ft}$. of underground workings and $900 \mathrm{fr}$. of seripping. Ore is chalcopyrice and pyrite that replaced and impregnaced greenscone in shear zone.

Mihelich and Wells, 1957 (RI 5320), p. 2 -- One of claims pacented by Threeman Mining Co.

p. 14 - Mine map [no sample data].

p. 19 -- Erosion along an eastward-scriking shear zone that dips $65^{\circ} \mathrm{N}$ resulted in a well-deflned, shallow crench that can be craced for more than a mile. Smaller subparallel shear zones contain pyrice and quartz. Tunnel driven northward Eor $400 \mathrm{ft}$. did not cross main shear zone or encounter significant sulfide mineralizarion. Sample of a quartz vein $1 \mathrm{Et}$. wide in a Eracture in greenstone contained $0.5 \%$ copper and 0.08 oz. $9 i$ lver and 0.18 oz. gold a ton.

Mackevett and Holloway, 1977 (OF 77-169A), P. [4, Loc. 9 - Reference to Capps and Johnsor, 1915 (B 605). Country rock chiefly greenstone of Orca Gp. 
(Port Etches)

Prince William Sound district
Copper

Cordova $(3.9,6.15)$

$60^{\circ} 21^{\prime} \mathrm{N}, 146^{\circ} 33^{\prime} \mathrm{W}$

Summary: Old copper prospect in volcanic unit of lower Tertiary Orca Gp.

Winkler, 1973 (MF-35l) -- Open workings of inactive, unpatented old copper prospect. In volcanic unit of lower Tertiary Orca Gp. 
(Red Head)

Prince William Sound distrlct

\section{Gold}

Cordova (4.4, 11.75$)$ approx. $60^{\circ} 40^{\prime} \mathrm{N}, 146030^{\prime} \mathrm{W}$ approx.

Summary: Gold in beach placer; derived from glacial gravels.

Johnson, B. L., 1913, field notes -- "Placer beach diggings on boch sides of Red Head - northern Port Gravina. A man will get from $\$ 1$ co 6 or 7 for a days work. Pieces as large as 5 cts worth found. Lors of mag sand:reporced. Placers are apparently beach wave concentration of glacial gravel banks visible along shore. Ruby sand beds reported up to $3 \mathrm{ft}$ thick." 
Reynolds-Alaska Developmenc Co. (Boulder Bay)

Prince William Sound discrice $M F-392$, loc. 7

\section{Copper}

Cordova $(3.2,15.5)$

$60^{\circ} 53^{\prime} \mathrm{N}, \quad 146^{\circ} 37^{\prime} \mathrm{W}$

Summary: More than 2,300 ft. of underground workings; several hundred tons of ore, some from 2 large bounders on beach, shipped before 1909. No work since then. Country rock is interbedded greenstone, graywacke, and slate of Orca Gp. Chalcopyrite in velns and disseminated in greenstone. See also Ripstein Ledge.

Grant, 1906 (B 284), p. 82-83 - Large boulders on beach made up of lron and copper sulfides. Tunnel run into mouncain from rear boulders to crosscut vein exposed in face of mountain; reported that "a vein carrying a good grade of chalcopyrite was struck" $400 \mathrm{ft}$. from porcal.

Moffic, 1908 (B 345), p. i78 -- Main cunnel extended, 1907.

Grant and Higgins, 1909 (B 379), p. 94 - More than 2,300 ft. of underground workings. Councry rock is interbedded greenstone, graywacke, and slate. Chalcopyrite in several veins and disseminated in greenstone. Several hundred tons of ore said to have been shipped; some of it came from 2 large boulders on beach.

Grant and Higgins, 1910 (B 443), p. 53 - Copper ore has been shipped.

p. 61 -- Same as Grant and Higgins, 1909 (B 379).

Capps and Johnson, 1913 (B 542), p. 115 -- Preliminary to Capps and Johnson, 1915 (B 605).

Capps and Johnson, 1915 (B 605), p. 57 - Daca from Grane and Higgins, 1909 (B 379).

p. 61 -- Data from Grant and HLggins, 1910 (B 443).

p. 103 -- Has been no development since visited by Grant and Higgins.

Moffit and Fellows, 1950 (B 963-B), p. 54-55 - Data from Grant and Higgins, 1910 (B 443).

Mackevett and Holloway, 1977 (OF 77-169A), p. 14, 10c. 6 -- Reference to Moffit and Fellows, 1950 ( $B$ 963-B). Country rock part of Orca Gp. 
Reyrolds-Alaska Development Co.

(Landlocked Bay)

Prince William Sound district

$M F-392$, LoC. 12
Copper

Cordova (3.75-4.1, 15.1-15.3)

$60^{\circ} 52^{\prime} \mathrm{N}, 146^{\circ} 32-146^{\circ} 34^{\prime} \mathrm{W}$

Sumnary: Discovered in about 1899. As of 1912 prospect consisted of about $900 \mathrm{ft}$. of underground workings, open cuts, and surface improvements. No record of any production. Ore in shear zones in interbedded greenstone, graywacke, and slate of Orca Gp. near and west of Landlock thrust ( In lower plate). Ore pyrrhotite with less abundant chalcopyrite in stringers and lenses as much as $4 \mathrm{ft}$. chick; replaced and impregnated sheared greenstone. Includes references to Cencaur and Standard claims.

Grant, 1906 (B 284), P. 84 -- Vein exposed on Centaur and Scandard clarms over a distance of $400 \mathrm{ft}$. Nearly vertical vein of chalcopyrite and pyrrhotite 2 in. to $3 \mathrm{ft}$. thick strikes $N 48^{\circ} \mathrm{E}$; in a shear zone.

Capps and Johnson, 1913 (B 542), p. 115-116 - Preliminary to Capps and Johnson, 1915 (B 605).

Capps and Johnson, 1915 (B 605), p. 102-103 - Discovered in about 1899. About $900 \mathrm{ft}$. of underground workings, open cuts, and various sur face improvements [as of 1912]. Ore in shear zones in incerbedded greenstone, graywacke, and slace west of and near Landlock chrust [in lower plate]. Ore consisrs mainly of pyrrhotice and less abundant chalcopyrite (besc assays showed $9 \%-10 \%$ copper; average much less) in gangue of quarcz, calclce, and sheared greenstone. Sulfide stringers and bodies [lenses?] as much as $4 \mathrm{ft}$. thick; replaced and impregnated sheared greenstone.

MoEfit and Fellows, 1950 (B 963-B), p. 59 -- Data from Capps and Johnson, 1915 (B 605) [not specifically cited].

Mihelich and Wells, 1957 (RI 5320), p. S 7 patented claims. Mackevert and Holloway, 1977 (OF 77-169A), p. 14, Loc. 8 -- Reference to Capps and Johnson, 1915 ( $B$ 605). In shear zones that cut rocks (mainly greenstone) of Orca $G p$. 
Ripstein Ledge

Prince William Sound district
Copper, Gold, Silver

Cordova (3.2, 15.5) approx.(?)

$60^{\circ} 53^{\prime} \mathrm{N}, 146037$ 'W approx.(?)

Summary: Sulfide ore (copper and iron sulfides) with quartz gangue in shear zone. Samples assayed as much as 0.1 oz. gold and 0.45 oz. silver a con. Deposit capped by a gossan beneath moss. By May, 1898, had been some strlpping. Daca somewhat amblguous; some or all may apply to deposit at Latouche (Seward quad.). Occurrence may be on some of ground that later became part of Reynolds-Alaska Developmenc Co. property on Boulder Bay. See also Reynolds-Alaska Development Co. (Boulder Bay).

Schrader, 1900, p. 418-419 - On NW base of Copper Mtn.; extends down nearly co tide level. Reported to have been discovered in 1897. May be on same shear zone as Alaska Commercial Co. Gossan beneach moss cover. Ledge is about $15 \mathrm{ft}$. chlck; dips about $80^{\circ} \mathrm{N}$ or is vertical. Fine-grained pyritiferous ore; apparently contains much marcasite; considerable purple copper ore mixed with quartz. Samples assayed as much as 0.1 oz. gold and 0.45 oz. silver a con. In May, 1898, had been uncovered for a discance of about $30 \mathrm{ft}$. [Or p. 419 table shows: Latouche Island, Ripscein Ledge, No. 140; gold (ounces per ton) - none; silver (ounces per con) - none; per cent copper -14.71.$]$ 
Prince William Sound district

Cordova $(3.05,15.55)$

$M E-392,10 C, 6$

$60^{\circ} 53^{\prime} \mathrm{N}, 146039^{\prime} \mathrm{W}$

Sumary: Sacks of copper ore on dump outside a short cunnel. Rocks on dump include quartzice and greenstone. See also Wagner.

Johnson, B. L., 1912-1917, field notes - At mourh of a cunnel about 45 ft. long there are sacks of $800 d$ copper ore on the dump. Rocks on dump are quartzite and greenstone. [Sphalerite and/or pyrthortte may be present; 2 ines of nores are nearly illegible.]

Mackevet and Holloway, 1977 (OF 77-169A), p. 14, loc, 6 - Reference to above. 
Schlosser

Prince William Sound districe $M F-392$, 10C. 19
Copper, Zinc

Cordova $(4.95,13.55)$

$60046^{\prime} \mathrm{N}, 146^{\circ} 25^{\prime} \mathrm{W}$

Summary: Deposit in closely Eolded and sheared graywacke, limestone, and ocher sedimentary rocks of Orca $\mathrm{Gp}$. Ore in crushed zone l50$200 \mathrm{ft}$. wide; sulfides occur as fracture fillings, impregnations, and replacements of country rock. Metallic minerals are chalcopyrite, pyrite, and (more rarely) pyrrhotite and sphalerlte; gangue is small amounts of quartz and calcite. Mine consists of several thousand feet of workings on 5 levels, some of which are connected by stopes. From 1913 (or probably a lictle earlier) until mine closed in 1920 shipped about 16,000 tons of ore that averaged about 10\% copper; one of the few mines in the bistrict co produce more than a million pounds of copper. Includes references co: Alaska Mines Corp., Fidalgo-Alaska Copper Co.

Grant and Higgins, 1909 (B 379), p. 96 -- Has been considerable stripping and several tunnels (longest with over $400 \mathrm{ft}$. of workings) driven (as of 1908). Country rock slate and a litcle graywacke. Chalcopyrice accompanied by a lictle pyrice occurs as cement in fractures, as irregular stringers, as digseminated grains, and as larger replacement bodies. Considerable amount of ore exposed; some ready Eor shipment.

Grant and H(ggins, 1910 (B 443), p. 63 - Same as above.

Brooks, 1912 (B 520), p. 27 -- Continued development, 19ll. Ore delivered to bunkers, but not shipped.

Brookg, 1913 (B 542), p. 34 -Development, 1912.

Brooks, 1914 (8 592), p. 62 -- Ore shlpment, 1913.

Johnson, 1914 (B 592), p. 240-242 - Discovered and development scarced, 1907 ; some development work and a small ore shipment, 1913; several hundred cons had been shlpped previously. Underground workings aggregate well over $1,100 \mathrm{ft}$. In length; considerable surface improvements.

Capps and Johnson, 1915 (B 605), p. L17-120 -- Extensive underground workings and surface excavations and improvemencs. Councry rock all sedimencary in origin (graywacke; argillite, slate, limetone, and finebanded siliceous rocks); closely folded and sheared. Ore is in a broad crushed zone l50-200 fc. wide: sulfides occur as fracture fillings, impregnations, and replacements of country rock; in one place chalcopyrite replaced sheared limescone. Small, irregulat wormlike channels in sedimentary rocks filled by chalcopycice, pyrite, and quartz. Metallic minerals are chalcopyrite, pyrice, pyrrhotice, and sphalerite (last two rare); gangue is small amoouncs of quartz and calcite. Very lictle surface alteration; no apparent enrichmenc. No data on gold or silver content.

Johnson, 1916 (B 642), p. 141 -- Underground development and repals of surface improvements, 1915. Ore shipment near end of year reported. 
Schlosser - cont.

Smith, 1917 (BMB 142), p. 38 - Underground development and surface improvements reported, 1915.

Smich, 1917 (BMB 153), p. 43 - Chalcopyrice and pyrice in lenses in a shear zone. 4 levels, all with some stopes; second and third levels connected.

Johnson, 1918 (B 662), p. 184 - Ore shipped, 1916.

p. 186-187 - About $650 \mathrm{ft}$. of underground workings reported to have been driven, 1916. Several ore shipments made.

Johnson, 1919 (B 692), p. 144 - Ore shipped, 1917.

p. 148-149 - - Several hundred feet of underground development work on 4 levels as well as stoping. Deposit is lenses of sulfides in a "linked system of shears." Ore zone is nearly vercical, strikes about $\mathrm{N} 20^{\circ} \mathrm{E}$, and is $100 \mathrm{ft}$. wide; ore shoots pitch to north.

Martin, 1919 (B 692), p. 31 -- Productive copper mine, 1917.

Marcin, 1920 (B 712), p. 33 -- Operated, 1918. Abour $690 \mathrm{ft}$. of new workings in ore zone.

Brooks, 1921 (B 714), P. 22 - In shear zone in slate and graywacke; slace sore crushed than graywacke.

Brooks and Martin, 1921 (B 7L4), p. 69 -- Some ore produced Incidental to development work, 1919.

p. 77 - Development continued, 1919.

Brooks, 1922 (B 722), p. 21 - Development continued, 1920.

p. 40 - hand-picked ore shipped, 1920. 1,450 fr. of main adit driven.

Moffit and Fellows, 1950 (B 963-B), P. 50-51 -n Produced more than one million pounds of copper.

p. 60-61 -- Small shipments of ore at Lrregular intervals before I916; regular shipments, 1916-20; tocal reported to have been about 16,000 tons that averaged about $10 \%$ copper. 5 principal adits; lowest was being drtven co undercut ore body at depth when mine closed in 1920 because of low copper price.

Moffle, 1954 (B 989-E), P. 298, 302 -- More than a million pounds of copper produced; came frora deposit in faulced sedimentary beds.

Berg and Cobb, 1967 (B 1246), p. 69-70--Quocation from Moffic, 1954 (B 989-E).

Mackevert and Holloway, 1977 (OF 77-169A), p. 14, 10c. 14 -- References to Capps and Johnson, 1915 ( $B$ 605) and MoEEIt and Fellows, 1950

(B 963-B). In sheared rocks of Orca Gp. 
Standard (Copper Mines Co.)

Prince William Sound district MF -392 , loc. 13
Copper, Gold, Silver, Zinc

Cordova $(3.55-3.75,15.05-15.15)$

$60052^{\prime} \mathrm{N}, 246034^{\prime}-146035^{\prime} \mathrm{W}$

Sumary: Chalcopyrite, pyrthotite, and sphalerite form lenses in sheared and faulted greenscone (some ellipsoidal) with incerbedded graywacke and slace of Orca Gp. Some ore bodies localized by incersections of shear zones or faults; gangue is quartz, calcite, and sheared, altered country rock. Ore formed by filling of fractures and replacement of sheared greenstone. Mine conslsted of 3 adics with cocal length of workings of about $1,300 \mathrm{fc}$; all driven bewteen 1906 and 1911. Production was 1, 100 tons of handsorted material that contained $32,000 \mathrm{lbs}$. copper and at leasc $36 \mathrm{oz}$. gold and 5.8 oz. silver (all gold and silver not reported) in 1907 and 1909 .

Grant and Higgins, 1909 (B 379), p. 95 - 3 ore-bearing zones exposed high on Copper Mtn. Tunnel $(2,000 \mathrm{ft}$. altitude) being driven to incersect ore zones was $420 \mathrm{ft}$. Long in August, 1908. One zone has been found and considerable ore mined and shipped. Second zone had not been recognized; tunnelchought to have reached third zone. Ore is in lens-shaped bodies in schisose parts of greenstone.

Brooks, 1910 (B 442), p. 39 - Production reported, 1909. Grant, 1910 (B 442), p. 165 -- Development work, 1909.

Grant and Higgins, 1910 (B 443), P. 52 - have been ore shipments.

p. 61-62 -- Same as Grant and Higglns, 2909 (B 379).

Brooks, 1912 (8 520), p. 27 - Development continued, 1911. In all there are $50 \mathrm{Et}$. of shaft and $1,100 \mathrm{ft}$. of cunnel.

Capps and Johnson, 1913 (B 542), p. 116-118 - Prellminary to Capps and Johnson, 1915 (B 605).

Capps and Johnson, 1915 (B 605), p. 57 -- Daca from Grant and Higgins, 1909 (B 379).

p. 61 - Daca from Grant and Higgins, 1910 ( $B$ 443).

o. 104-106 - Aboue 1,300 ft. of underground workings driven, 1906-11; a few cons of ore reported ro have been shipped. Idle, 1912-13. Country rock is mainly greenstone (some ellipsoidal) and small amounts of incerbedded graywacke and slace; all much sheared and faulted. Sulfides are in shear zones $1-20 \mathrm{ft}$. wide and have replaced sheared greenscone and Eilled fractures. Sulfides are chalcopyrite, pyrrhotite, and sphalerite in scringers and lenses; gangue is quartz, calclte, and sheared, altered country rock. Some sulfide bodies are at intersections of shear zones.

Johnson, 1915 (B 622), p. 133 - No mining, 1914.

Johnson, 1916 (B 642), p. 141 -- No work, 1915.

Johnson, 1918 (B 662), p. 186 - Reported chat rehabilitation of surface plant began in Nov., 1916.

Johnson, 1919 (B 692), p. 148 -- Some surface and underground work in 1917. By October only watchman on premises. 
Standard (Copper Mines Co.) -- conc.

Moffit and Fellows, 1950 (B 963-B), p. 58-59 -- Data Erom Grant and Higgins, 1910 (B 443) and Capps and Johnson, 1915 (B 605).

Mihelich and Wells, 1957 (RI 5320), p. 3 - Data on claims.

p. 5-6 -- Extensive surface Lnscallations and underground developments completed by 1911. Production in 1907 and 1909 amounted to 1,100 tons of ore chat concained 32,000 lbs. copper, and at least $36 \mathrm{oz}$. gold and $5 \mathrm{l} 8$ oz. Silver (all of gold and silver not reported).

p. 10 -- Mine map. Samples assayed contained as much as $6.1 \%$ $\mathrm{Cu}, 0.78 \% \mathrm{Zn}$, and 0.1 oz. Silver and $0.05 \mathrm{oz}$. gold a con.

p. 16-17 -- Claims actively explored and developed, 1906-11. Shipments of 1,100 tons of hand-sorted ore containing almost $1.5 \%$ copper with some gold and silver made in 1907 and 1909. Mine consisted of 3 adits wich a cotal lengch of $1,250 \mathrm{ft}$. Ore bodies are small lenticular masses of chalcopyrice, pyrite, and pyrrhotite at or near intersections of shear zones or faults in predominantly greenstone country rock.

Mackevert and Holloway, 1977 (OF 77-169A), p. 14, loc. 9 -- References to Capps and Johnson, 1915 (B 605) and Mihelich and Wells, 1957 (RI 5320). Country rock chlefly greentone of Orca $G$. 
Nizina district

Cordova $(22.4,17.15)$

$M F-392$, Loc. 30

$60057^{\prime} \mathrm{N}, 144022^{\prime} \mathrm{W}$

Summary: Quartz vein a litcle more that a foot thick contains visible gold, pyrite, and galena; assays of about 2.9 oz. gold a con reported; higher assays from picked specimens. Shallow shafe was only development; no record of production. Chalcopyrite also present in other veins in neighborhood.

Moffic, 1914 (B 576), p. 51 - Shallow vercical shaft sunk on a norchward-striking, eastward gently dipplng quartz vein a lictle more than a foot thick in schist. Vein carried visible gold, pyrtte, and galena; assays of $\$ 60$ [about 2.9 fine oz.] a ton; higher from picked specimens. A little chalcopyrite in similar velns in neighborhood.

Berg and Cobb, 1967 (B 1246), p. 63 -- Data from above [not specieically cited].

Mackevert and Holloway, 1977 (OF 77-169A), p. 15, Loc. 23 -- Reference to Moffit, 1914 (B 576). Schlst is part of Valdez Gp. 
Steinmetz

Prince Williara Sound district

MF-392, Loc. 14
Copper, Gold, Silver

Cordova $(3.9,15.0)$

$60^{\circ} 51^{\prime} \mathrm{N}, 146^{\circ} 32^{\prime} \mathrm{W}$

Sumary: Smal1-scale underground and surface exploration of a shear zone in greenscone of Orca $\mathrm{Gp}$. Shear zone contains lenses of chalcopyrite and pyrrhotite in quartz and calcite gangue. Lenses 2 in. to $4 \mathrm{ft}$. thick; one is $35 \mathrm{ft}$. long. 6 tons of ore containing $6 \%$ copper reported to have been shipped before 1913. Assays of samples showed from craces to as much as 0.11 oz. gold and 0.01 oz. silver a ton. Includes reference to Alaska Pioneer and Sourdough claims. See also Tibbits; Steinmetz restaked one or more of his claims.

Capps and Johnson, 1925 (B 605), p. 110-111- In 1913 developments consisted of a 40-ft. adit, a $25-f t$. shate, and several open cuts. 6 cons of ore contalning $6 \%$ copper said to have been shlpped. Bodies of chalcopyrite and pyrchocite in quartz and calcite gangue are in shear zones in greengtone, graywacke, and slate. Shear zone from which ore was mined strikes $N 64^{\circ} \mathrm{E}$, dips $65^{\circ} \mathrm{NW}$, and contained lenses of ore $2 \mathrm{in.} \mathrm{to} 4 \mathrm{ft}$. Wide. Nearby there are several nearly parallel mineralized shear zones.

Mihelich and Wells, 1957 (RI 5320), p. 12 -- Map of prospect. Samples assayed contained as much as $3.9 \% \mathrm{Cu}$ and $0.11 \mathrm{oz}$. gold and $0.0 \mathrm{oz}$. silver a ton.

p. $18--65 \mathrm{ft}$. of cunnel and a shallow vertical shaft driven to explore shear zone (strike N600E, dip 700N) in greenstone. Lens of chalcopyrite and pyrrhotice is $1.5-3.0 \mathrm{ft}$. wide and $35 \mathrm{ft}$. long. Mackevec and Holloway, 1977 (OF 77-169A), p. 14, lac. 10 - Reference to Capps and Johnson, 1915 (B 605). Country rock chiefly greenstone of Orca Gp. 
Threeman Mlning Co. (Billygoat Mtn.) Copper

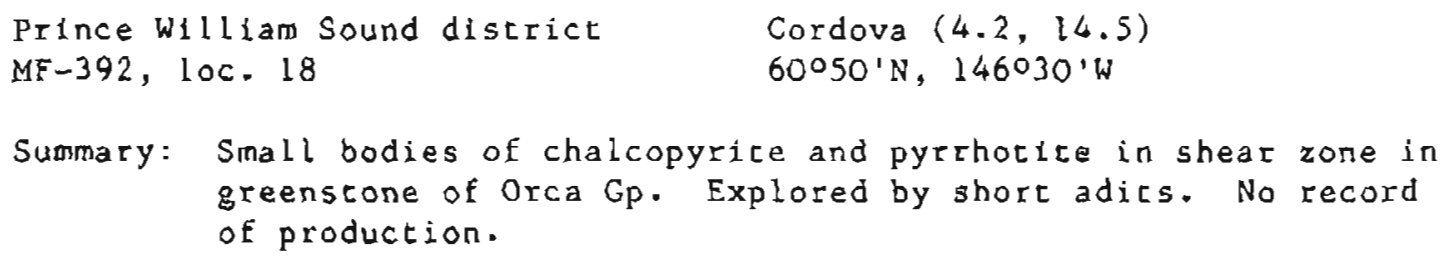


Threeman (Mining Co.) (main mine) Copper, Gold, Lead, Silver, Zinc

Prince William Sound district Cordova (3.9-4.05, 14.9-15.l)

$M F-392$, Loc. $14 \quad 60051^{\prime} \mathrm{N}, 146032^{\prime}-146033^{\prime} \mathrm{W}$

Sumary: Country rock is sheared and faulted incimately mixed greenscone and sedimentary rocks (largely graywacke) of Orca $\mathrm{Gp}$. in lower place west of Landlock thrust. Lenticular masses of sulfides in 2 subparallel shear zones. Ore consists of chalcopyrice, pyrrhotite, sphalertte, cubanice, and galena; small amourts of gold and silver. A little natlve copper in weathered outcrops. A sample taken for metallurgical testing contained $0.01 \% \mathrm{Ni}$ and $0.02 \%$ Co. Ore formed by open-space filling and replacement of sheared country rock. Mine consists of more than 5,000 ft. of workings on 5 levels. Between 1904 and 1915 shipped about 6,000 cons of ore containing about $1,214,000$ ibs. copper, more than 115 oz. gold, and more ehan 1,508 oz. silver (data on gold and silver incomplete). Little work and no production after 1915. Includes references to: Dickey, Keyscone. See also Hoodoo.

Grant, 1904 (B 284), p. 84 -- 3 tunnels (longest $50 \mathrm{ft}$. long) have been driven along shear zone with a layer of fairly solid sulfides from l in. to $2 \mathrm{ft}$. wide (disseminated chalcopyrite in sheared councry rock on hanging-wall side); strtkes eastward and dips northward. Has been a small shipment of ore.

Granc and Higgins, 1909 (B 379), p. 95 -- Considerable developmenc work; several veins of chalcopyrite and pyrrhotite in shear zones in greenstone, graywacke, and slate. Ore in lens-shaped bodies from a few inches to a few feet thick. Have been (as of 1908) small shipments; more ore ready to ship; most of work has been development rather than mining.

Grant, 1910 (B 442), p. 165 m Development work; a few hundred tons of ore mined, 1909.

Grant and Higgins, 1910 (B 443), p. 52 - Copper ore has been shipped.

p. 53-55 -- Native copper present. Chalcopyrite, pyrrhotite, and pyrice have been deposiced along shear zones as impregnations and replacements of country rock.

p. 61-62 -- Same as Grant and Higgins, 1909 (B 379).

Brooks, 1912 (B 520), P. 27 - Ore shipped, 1911. Workings aggregare $5,000 \mathrm{ft}$. on 5 levels.

Capps and Johnson, 1913 (B 542), P. 97, 101-102, 108-110 - Preliminary to Capps and Johnson, 1915 (B 605).

Brooks, 1914 (B 592), p. 62 -- Development work, 1913.

Johnson, 1914 (B 592), p. 24l - Development, but no ore shipped, 1913.

Capps and Johnson, 1915 (B 605), p. 24 - Staked in 1903; small sample shipments in 1904 and 1906 ; regular shipments began in 1911 .

p. 51 -- Productive mine, 2912.

p. 56-57, 61 -- Data from older reports sumbarized or quoced.

p. 70-72 - Unknown sulfide mineral intimately associaced with 
Threeman (Mining Co.) (main mine) - cont.

chalcopyrite [unknown sulfide tacer determined to be cubanite]. This mineral, chalcopyrite, and galena are younger than pyrrhotite in the ore. Assays indicace the presence of gold. Flakes of native copper in weathered outcrops.

p. 92-96 -- Historical data summarized. In 1912 mine was a regular shipper; no ore shipped in 1913. In 1912 the mine consisted of $2,000 \mathrm{ft}$. of underground workings on 5 levels at from 57 co 282 ft. above sea level. Country rock is greenstone, graywacke, and slate of Orca Gp.; just west of trace of Landlock thrusc; in lower plate; intensely shattered, sheared, and taulted. Workable ore bodies are 2 lenticular masses of nearly solid sulfides (chalcopyrite, pyrrhotite, sphalerice, pyrite, and [cubanite] in mineralized shear zones; from 1 to $9 \frac{1}{2}$ Ec. chick in workings. Dimensions of ore bodies not established; stope lengch of one appears to be about 80 ft. Cangue is quartz, calcite, and sheared and alcered councry rock. Deposit formed by replacemenc and cementation of fractured rock in shear zones.

Johnson, 1916 (B 642), p. 138, 140 -- Several shipments of ore, 19L5. Sm1th, 1917 (BMB 142), p. 43 -- Ore bodies in shear zones opened by over $2,000 \mathrm{ft}$. Of workings on 5 levels.

Snich, 1917 (BMB 153), P. 50 -- Same as above.

Johnson, 1918 (B 662), p. 184 - No ore shipped, 1916.

p. 186 - Underground development, but do ore shipped, 1916.

Johnson, 1919 (B 692), g. 144, 148 -- Very little work and no ore shipped, 1917.

Marcin, 1920 (8 712), p. 33 -- Some ore mined but not shlpped, 1918.

Brooks, 1923 (B 739), p. $24-$ No work, 1921.

Moffir and Fellows, 1950 (B 963-B), p. S0-51 -- More than a million pounds of copper produced.

p. 57 -- More chan $5,000 \mathrm{ft}$. of underground workings on 5 levels; $5,000-6,000$ tons of $8 \%$ ore shipped, 1904-15. Ore mainly from 2 léacicular bodies of nearly solid sulfides in faulted and shactered greenstome, graywacke, and slace west of Landlock thrust.

Moffit, 1954 (B 989-E), p. 298, 302 - Produced more than a million pounds of copper. Ore from considerably faulted intimately mixed greenstone and sedimentary rocks. Considerable cubanite associated with chalcopyrice in Lanlocked Bay area.

Wells, 1956 (RI 5254), p. 1, 5-6 -- Data on flotation tescs of composite channel sample of copper ore that contained $1.65 \% \mathrm{Cu}, 0.01 \% \mathrm{Ni}, 0.02 \%$ Co, tr. Au, and $0.36 \mathrm{oz}$. a ton Ag. Concentrate contalned $81 \%$ of cop per in heads in a product contalning $28.4 \% \mathrm{Cu}$.

Mihelich and Wells, 1957 (RI 5320), p. 3 - Data on claims.

p. 5-6 -- Between 1904 and 1915 shipped abour 6,000 cons of ore containing about $1,214,000$ lbs-copper, more than 115 or. gold, and roore than 1,508 oz. Silver (data in gold and silver incomplete).

p. 7-9 -- Mine map and sections; USBM reopened and recimbered some of workings. Samples assayed as rouchas $8.60 \% \mathrm{Cu}, 0.64 \% \mathrm{Zn}$, 
Threeman (Mining Co.) (main mine) - cont.

$0.78 \mathrm{oz}$. a ton $\mathrm{Ag}$, and $0.07 \mathrm{oz}$. a ton $\mathrm{Au}$.

p. 16 - Data on production about as on p. 6 ; ore averaged $9.2 \%$ copper. Deposit staked in 1903; last activity in 1916. 5 levels of workings; rotal length over $5,000 \mathrm{ft} . ;$ in 2 roughly parallel shear zones in greenstone, graywacke, and slace in footwall of landlock thrust faule. Shear zones $15-50 \mathrm{ft}$. wide, strike 600-70\%, and dip $\mathrm{N}$; diverge downward. Ore formed by open-space filling and replacement of sheared macerial; in 2 lenticular almost massive bodies of chalcopyrice and pyrthotite. Largest body mined had stope length of $70 \mathrm{ft}$., width of $2-9 \frac{1}{2} \mathrm{ft}$. , and was mined for $350 \mathrm{ft}$. along dip. Composice sample of ore concained chalcopyrite, pyrite, pyrrhotice, a very small amount of sphalerice, and quarcz, calcice, and othet gangue. Channel samples show the remaining ore to contain $0.3 \%-8.6 \% \mathrm{Cu}$, as much as $0.6 \% \mathrm{Zn}$, and "unimporeane amouncs of gold and silver."

p. 19-21 - Data on flotation rests or ore are about as in Wells, 1956 (RI 5245).

Berg and Cobb, 1967 (B 1246), p. 69-70-- Quotation Erom Moffit, 1954 (B $989-E)$.

Mackevett and Holloway, 1977 (OF 77-169A), p. 14, Loc. 10 -- References to Capps and Johnson, 1915 (B 605) and Mihelleh and Wells, 1957

(RI 5320). Councry rock mainly greenstone of Orca GP. 


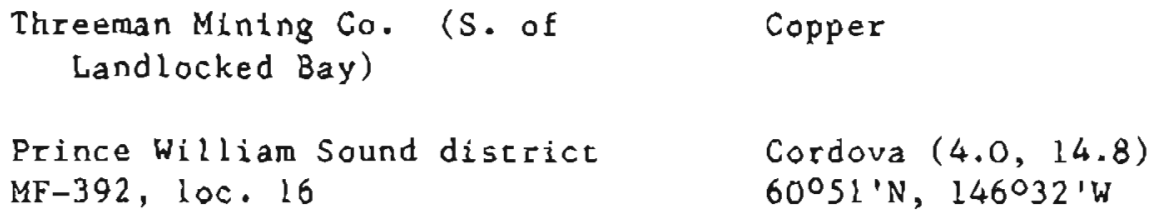

Sumary: Minor underground and surface exploration of small shear zones in volcanics and incerbedded slate and graywacke of orca Gp. Only small amounts of chalcopyrite and pyrrhotite.

Capps and Johnson, 1913 (8 542), p. 121-122 -- Preliminary to Capps and Johnson, 1915 (B.605).

Capps and Johnson, 1915 (B 605), p. $109-4$ adits between 115 and 5 ft. long driven in slightly minerallzed shear zones in incerbedded black slate, graywacke, and greenscone; small amouncs of chalcopyrite and pyrrhotite in both greenstone and slace. Scripped outcrops iron stained in places; exceptionally litcle copper staining. Mackevert and Holloway, 1977 (OF 77-169A), p. 14, loc. Il -- Reference to Capps and Johnson, 1915 (B 605). Country rock volcanics of Orca Gp. 
Tibbees

Prince William Sound district MF-392, Loc. Ll
Copper, Gold

Cordova $(3.75,15.25)$

$60^{\circ} 52^{\prime} \mathrm{N}, 146034^{\prime} \mathrm{W}$

Sumary: A litcle copper raineralization in shattered greenstone. Float reported to carry about 1.9 fine. oz. gold a con.

Johnson, B. L., 1912-1917, field notes -- Float in gulch reported co run $\$ 40$ in gold. Rock on dump outside a tunnel $15 \mathrm{ft}$. long looks like shaccered greenscone cemented by quartz stringers. A litcle copper in tunnel - "a speck or two but it didnt amount to anyching." Several other prospect openings show a little copper stain.

Mackevett and Holloway, 1977 (OF 77-169A), p. 14, Loc. 7 -- Reference co above. 
Wagner

Prince William Sound district

$M F-392,10 c .6$

\section{Copper}

Cordova $(3.05,15.55)$

$60^{\circ} 53^{\prime} \mathrm{N}, 146039^{\prime} \mathrm{W}$

Summary: Chalcopyrite in quartz in shear zone in graywacke and greenscone.

Johnson, B. L., 1912-1917, field notes -- Tunnel driven $285 \mathrm{ft}$. on shear zone in graywacke and greenstone. Gouge zone near face. Chalcopyrite in quartz Eragments on dump.

Mackevett and Holloway, 1977 (OF 77-169A), p. 14, loc. 6 -- Reference to above. 
Whalen \& Nelson

Prince William Sound district

MF-392, loc. 22
Copper

Cordova $(7.4,14.3)$

$60^{\circ} 49^{\prime} \mathrm{N}, 146^{\circ} 08^{\prime} \mathrm{W}$

Summary: Irregular stringers and disseminaced grains of chalcopyrite and pyrrhotitie in rocks of Orca Gp. A little explorarion, but no recorded production, in early $1900^{\prime} \mathrm{s}$.

Grant and Higgins, 1909 (B 379), p. 96 - Stripping and a small cunnel. Ore in a hard band of nonslaty rock commonly 2-4 Et. thlck, but as much as $12 \mathrm{ft}$. thick, in councry rack that is mainly slace. Ore is irregular scringers and dlsseminaced grains of chalcopyrite and pyrrhotice.

Grant and Higgins, 1910 (B 443), p. 62-63 - Same as above.

Mackevett and Holloway, 1977 (OF 77-169A), p. 15, 10c. 16 -- Reference to Grant and Kiggins, 1910 (B 443). Country rock part of Orca Gp. 
(WILson Point)

Prince William Sound discrict

MF-392, loc. 24
Gold, Silver

$$
\text { Cordova ( } 11.45,11.6)
$$

$60^{\circ} 39^{\prime} \mathrm{N}, 145^{\circ} 40^{\prime} \mathrm{W}$

Summary: Quartz veinlets in shear zone in sedimentary rocks of Orca Gp. contain gold and silver. One sample assayed 1.25 oz. gold and 3 oz. silver a ton.

Schrader, 1900, p. 421 -- Vertical shear zone contains many parallel quartz stringers or velnlecs; thickness of stringer lode is about $3 \mathrm{ft}$. Sample assayed $1.25 \mathrm{oz}$. gold and $3 \mathrm{oz}$. silver (value about \$27) a ton. Warrants further investigation.

Berg and Cobb, 1967 (B 1246), p. 73 - Unproductive quartz veins prospected near lackpot Bay [Seward quad.] and Wilson Point.

Mackevett and Holloway, 2977 (OF 77-169A), p. 15, loc. 18 -- Reference to Schrader, $1900, \mathrm{p}$. 421. Occurrence in sedimentary rocks of Orca Gp. 
Unnamed occurrence

Prince William Sound district
Gold $(?)$

Cordova $(4.7,17.15)$ $60^{\circ} 59^{\prime} \mathrm{N}, 146^{\circ} 26^{\prime} \mathrm{W}$

Sumary: Quartz vein as much as 3 ft. chick contalns a little arsenopyrite and possibly traces of gold.

Johnson, 1919 (B 692), p. 173 -- Quartz vein 6 in. to 3 Et. thick strikes $\mathrm{N} 40^{\circ} \mathrm{E}$ and dips $60^{\circ} \mathrm{W}$; is craceable for several hundred feet in outcrops. Crosscuts bedding of massive finemgrained graywacke. Not well mineralized; only visible minerals are quartz, arsenopyrite, and limonite; traces of gold reporced to have been shown by assays. 
Synonyms, Claim Names, Oparators, and Owners

Many mines and prospects have undergone changes in boch cheit own names and in the names of cheir operacorg and owners. All names ehat appear in che clced references appear in ehis sumbary eicher in che first section as occurrence names or th this saccion as syronyms. 
A.C. (Co.) - see Alaska Comercial Co.

Ajax - see Moncezuma

Alaska -r see Steinmetz

Alaska Copper Corp. -- see Schlosier

Alaska Mines Corp. -- see Schlosser

Alaska Ploneer -- see Sceinmetz

Alaska Standaro Copper Mining Co. - see Standard Copper Mines Co.

Alice T. - see Standard Copper Mines Co.

American Girl -m see Galena Bay Mining Co.

Anvil mee Galena Bay Mining Co.

Apex - see Standard Copper Mines Co.

Banta \& Cameron - see Mogul

Beach -- see Reynolds-Alaska Development Co (Landlocked Bay)

Black Bear - see Dickey Copper Co.

Blakney (\& Herren) -- see Fidalgo (Mining Co.)

Buckeye - see Montezuma

Burke \& Steele - see Standard Copper Mines Co.

Centaur - see Reynolds-Alaska Developmene Go. (Landlocked Bay)

CIiff - see Moncezuna

Comet -- see Standard Copper Mines Co.

Copper King -- see Ellamar

Copper Mouncain - see Alaska Commercial Co.

Copper Queen -- see Galena Bay Mining Co.

Cordova-Tacoma Copper Co. -- see Head-of(-the)-Bay

Cornet - see Scandard Copper Mines Co.

Daisy - see Montezuma

Dickey -- see Threeman

Discovery - see Threeman

Dolan \& Rystrom -- see Landlock Bay Copper Mining Co.

Elgin -- see Fidalgo (Mining $C_{0 .}$ )

Fidalgo-Alaska Copper Corp. - see Schlosser

Fidalgo (Landlocked_Bay) -- see Hemple Copper. Co.

(Fleming Sple) - see Cordova Copper Co.

Forget-me-Not - see Galena Bay Mining Co.

(Galena Bay) -- see Galena Bay Mining Co.

Gladhaugh (\& Peterson) -- see Ellamat

Gladhaugh Bay - - see El lamar

Gleason -- see Dickey Copper Co.

Grizzly -- see Reynolds-Alaska Development Co. (Landlocked Bay)

Grove - see Hoodoo

Hemple Mining Co. -- see Hemple Copper Co.

Hendrie \& Simenscad -- see Galema Bay Mining Co.

Honestake -- see Galena Bay Mining Co.

Hornec's Nest - see Galena Nay Mining Co.

Irish Cove (Copper Co.) -- see Dickey Copper Co. 


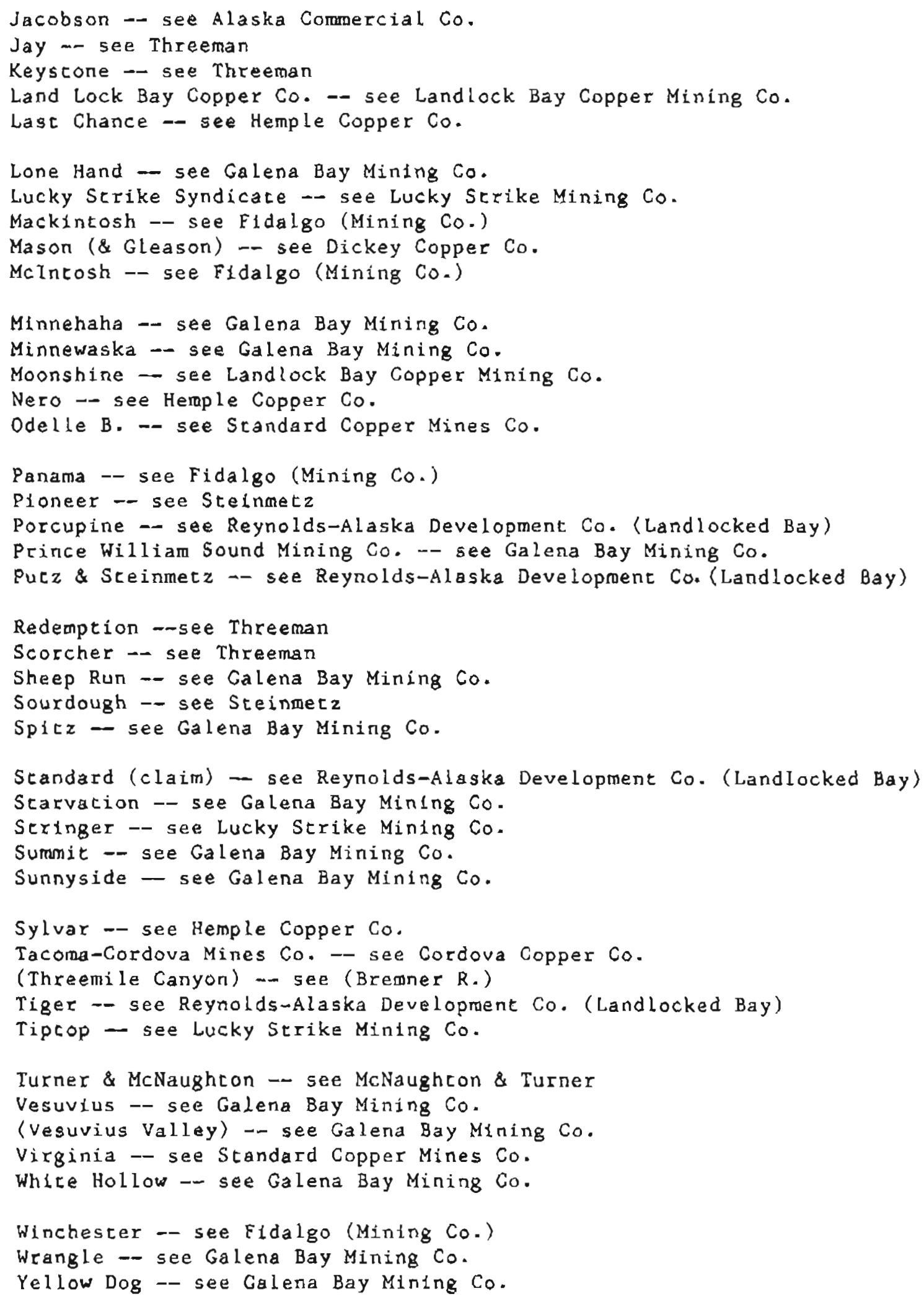


References Cited

Cordove quadrangle

Bain, H. F., 1946, Alaska's minerals a a basis for lndustry: U.S. Bureeu of Mines Information Circular 7379,89 p.

Berg, B. C., and Cobb, E. H., 1967, Metalifferous lode deposits of Alaske: U.S. Geologlcal Survey Bulletin 2246, 254 p.

Brooks, A. H., 1907, The rining industry in 1906: U.S. Geological . Survey Bulletin 314, p. 19-39.

Brooks, A. H., 1910, The mining industry in 1909: U.S. Geological Survey Bulletin 442 , p. $20-46$.

Brooks, A. H., 1911, The mining industry in 1910: U.S. Geological Survey Bulletin 480 , p. 21-42

Brooks, A. H., 1911, Geologic features of Alaskan metalliferous lodes: U.S. Geological Survey Bulletin 480, p. 43-93.

Brooks, A. H., 1912, The mining industry in 1911: U.S. Geological Survey Bulletin 520, p. $17-44$.

Brooks, A. B., 1913, The mining 1ndustry in 1912: U.S. Geologleal Survey Bulletin 542, p. 18-51.

Brooks, A. H., 1914, The Alaskan mining industry in 1913: U.S. Geological Survey Bulletin 592 , P. 45-74.

Brooks, A. H., 1915, The Alaskan mining industry in 1914: U.S. Geological Survey Bulletin 622, p. 15-68.

Brooks, A. H., 1918, The Alaskan mining industry in 1916: U.S. Geological Survey Bulletin 662, p. 11-62.

Brooks, A. H., 1921, The future of Alaska mining: U.S. Geological Survey Bulletin 714, p. 5-57.

Brooks, A. H., 1922, The Alaskan ming tudustry in 1920: U.5. Geologlcal Survey Bulletin 722, p. 7-67.

Brooks, A. B., 1923, The Aleska mining tudustry in 1921: 0.s. Geological Survey Bulletin 739, p. 1-44. 
Brooks, A. H., and Capps, S. R., 1924, The Alaske mining industry in 1922: U.S. Geological Survey Bulletin 755, p. 3-49.

Brooks, A. H., and Martin, G. C., 1921, The Alaskan mining industry in 1919: U.S. Geological Survey Bulletin 714, p. 59-95.

Capps, S. R., and Johnson, B. L., 1913, Mineral deposits of the Ellamar district: U.S. Geological Survey Bulletin 542, p. 86-124.

Capps, S. R., and Johnson, B. L., 1915, The Ellamar district, Alaska: U.S. Geological Survey Bulletin 605, $125 \mathrm{p}$.

Cobb, E. H., 1972, Metallic mineral resources map of the Cordova quadrangle, Alaska: U.S. Geological Survey Miscellaneous Fleld Scudies Map MF $-392,1$ sheet, scale $1: 250,000$.

Cobb, E. H., 1973, Placer depostts of Alaska: 0.S. Ceological Survey Bulletin 1374, $213 \mathrm{p}$.

Cobb, E. H., and Kachadoorian, Reuben, 1961, Index of metallic and nonmetallic mineral deposits of Alaska complled from publighed reports of Federal and Scate agencles through 1959: U.S. Geological Survey Bullecin 1139, 363 p.

Condon, W. 4., 1965, Map of eastern Prince william Sound area, Alaska, showing fracture traces Inferred from aerial photographs: U.S. Geologlcal Survey Miscellaneous Geologic Investigations Map $[-453,4$ p., I sheet, scale $1: 125,000$.

Chapin, Theodore, 1913, The Mckinley lake district: U.S. Geological Survey Bullesin 542, p. 78-80.

Grant, U. S., 1906, Copper and other rolneral resources of Prince William Sound: U.S. Geological Survey Bullecin 284, p. 78-87.

Grant, U. S., 1910, Mining and prospecting on Prince William Sound in 1909: U.S. Geological Survey Bulletin 442, p. 164-165.

Grant, U. S., and Higgins, D. F., Jr., 1909, Copper mining and prospecting on Prince William Sound: U.S. Geological Survey Bulletin 379, p. 87-96.

Grant, U. S., and Higgins, D. F., 1910, Reconnaigsance of the geology and mineral resources of Prince William Sound, Alaska: U.S. Ceological Survey Bullertn 443, $89 \mathrm{p}$. 
Henning, M. W., and Dobey, F., 1973, Geologic and mineral evaluation of the Chitina and Bremer River drainage basins: Alaska Division of Geological and Geophysical Surveys Open-file Report AOF-25, $20 \mathrm{p}$.

Johnson, B. L., 1914, Mining on Prince W1lllam Sound: U.S. Geologica1 Survey Bullectn 592, p. 237-243.

Johnson, B. L., 1915, Mining on Prince William Sound: U.S. Geological Survey Bulletin 622, p. 131-139.

Johnson, B. L., 1916, Mining on Prince William Sound: U.S. Geological Survey Bullerin 642, p. 137-145.

Johnson, B. L., 1918, Mining on Prtnce William Sound: U.S, Geo- logical Survey Bulletin 662, p. 183-192.

Johnson, B. L., 1919, Mining on Prtnce William Sound: U.S. Geological Survey Bulletin 692, p. 143-151.

Johnson, B. L., 1919, Mineral resources of Jack Bay district and viclnity, Prince William Sound: U.S. Geological Survey. Bulletin 692, P. 153-173.

Koschmann, A. H., and Bergendahl, M. H., 1968, Principal goldproducing districts of the Untred Stares: U.S. Geological Survey Professional Paper 610, $283 \mathrm{p}$.

Mackevett, E. M., Jr., and Holloway, C. D., 1977, Map showing metalliferous and selected nonmetalliferous mineral deposits in the eastern part of southern Alaska: U.S. Geological Survey Open-file Report 77-169A, I sheet + 99 p. tabular material, scale $1: 1,000,000$.

Mackevetr, E. M., Jr., Singer, D.A., and Holloway, C. D., 1978, Maps and rables describing metalliferous mineral resource potential of souchern Alaska: U.S. Geological Survey Open-Eile Report 78-1-E, 45 p. + maps, scale $1: 1,000,000$.

Martin, G. C., 1919, The Alaskan mining industry in 1917: U.S. Geological Survey Bulletin 692, p. 11-42.

Martin, G. C., 1920, The Alaskan mining industry 1n 1918: U.S. Geologlcal survey Bulletin $722, \mathrm{p} .12-52$. 
Mihelich, Miro, and Wells, R. R., 1957, Copper mines and prospects adjacent to Landlocked Bay, Prince William Sound, Alaska: U.S. Bureau of Mines Report of Investigations 5320, 21 p.

Moffic, 8. H., 1908, Notes on copper prospects of Prince William Sound: U.S. Geological Survey Bulletin 345, p: 176-178.

Moffit, F. H., 1912, The Taral and Bremner River districts: U.S. Geological Survey Bulletin 520, p. 93-104.

Moffit, F. H., 1914, Geology of the Hanagita-Bremner region, Alaska: U.S. Geological Survey Bulletin 576, 56 p.

Mofe1t, F. H., 1954, Geology of the Prince William Sound region, Alagka: U.S. Geological Survey Bulletin 989-E, p. 225-310.

Moffit, F. H., and Fellows, R. E., 1950, Copper deposits of the Prince Whlliam Sound district, Alaska: U.S. Geological Survey Bulletin $963-B$, p. $47-80$.

Mulligan, J. J., 1974, Mineral resources of the trans-Alaska pipeline corridor: U.S. Bureau of Mines Informetion Circular 8626, 24 p.

Ransome, A. L., and Kerns, W. H., 1954, Names and definttions of regions, districts, and subdistrices in Alaska (used by the Bureau of Mines in statistical and economic studies covering the mineral industry of the Territory): U.S. Bureau of Mines Information Circular 7679 , $91 \mathrm{p}$.

Reimitz, Erk, and Plafker, George, 1976, Martne gold placers along the Gulf of Alagka margin: U.S. Geological Survey Bulletin 1415 , $16 \mathrm{p}$.

Schrader, F. C., 1900, A reconnaissance of a part of Prince William Sound and the Copper River district, Alaska, in 1898: U.S. Geollogical Survey 20th Annual Report; part 7, p. $341-423$.

Schrader, F. C., and Spencer, A. C., 190l, The geology and mineral resources of a portion of the Copper River district, Alaska: U.S. Geological Survey Special Publication, $94 \mathrm{p}$.

Sralth, P. S., 1926, Mineral industry of Alaska in 1924: U.S. Geological Survey Bulletin 783, p. 1-30.

Sintth, P. S., 1929, Mine ral 1ndustry of Alaske 1n 1926: U.S. Geological Survey Eulletin 797, p. 1-50. 


\section{Cordova quadrangle}

Sultb, P. 8., 1932, Mineral industry of Alaska In 1929: U.S. Geological Survey Bulietin 824, p. 1-81.

Srith, P. S., 1933, Mineral industry of Alaska in 1930: U.S. Geological Survey Bullecin 836 , p. 1-83.

Smith, S. S., 1917, The mining industry in the Terricory of Alaska during the calendar year 1915: U.S. Bureau of Mines Bulletin $142,66 \mathrm{p}$.

Sinth, S. S., 1917, The minting industry in the Terrltory of Alaska during the calendar year 1916: U.S. Buraau of Mines Builetin $.153,89 \mathrm{p}$.

Wells, R. R., 1956, Laboratory concentracion of various Alaska copper ores: U.S. Bureau of Mines Report of Investigations 5245,9 p.

Hinkler, G. R., 1973; Geologic map of the Cordova A-7 and A-8, $B-6, B-7$, and B-8 quadrangles, Hinchinbrook Island, Alaska:

U.S. Geological Survey Miscellaneous Field Studies Map MF-531, 1 sheet, scale $1: 63,360$.

Wholer, G. R., Mackevett, E. M., Jr, and Nelson, S. W., 1977, Strata-bound iron-copper-zine sulfide deposits, Prince Wrlliam Sound region, southern Alaska, In Blean, K. M., ed., The Unlted Staces Geological Survey in Alaska: accomplishmencs during 1976: U.S. Geological Survey Circular 751-B, p. B44-845. 